\title{
Role of renal vascular potassium channels in physiology and pathophysiology
}

\author{
Salomonsson, Max; Brasen, Jens Christian; Sorensen, Charlotte Mehlin
}

Published in:

Acta Physiologica

Link to article, DOI:

10.1111/apha.12882

Publication date:

2017

Document Version

Peer reviewed version

Link back to DTU Orbit

Citation (APA):

Salomonsson, M., Brasen, J. C., \& Sorensen, C. M. (2017). Role of renal vascular potassium channels in physiology and pathophysiology. Acta Physiologica, 221(1), 14-31. https://doi.org/10.1111/apha.12882

\section{General rights}

Copyright and moral rights for the publications made accessible in the public portal are retained by the authors and/or other copyright owners and it is a condition of accessing publications that users recognise and abide by the legal requirements associated with these rights.

- Users may download and print one copy of any publication from the public portal for the purpose of private study or research.

- You may not further distribute the material or use it for any profit-making activity or commercial gain

- You may freely distribute the URL identifying the publication in the public portal

If you believe that this document breaches copyright please contact us providing details, and we will remove access to the work immediately and investigate your claim 
Received Date : 15-Mar-2016

Revised Date : 02-Mar-2017

Accepted Date : 22-Mar-2017

Article type : Review Article

\section{Role of renal vascular potassium channels in physiology and pathophysiology}

Max Salomonsson ${ }^{1}$, Jens Christian Brasen ${ }^{2}$ and Charlotte M. Sorensen ${ }^{3}$

${ }^{1}$ Medical Ward 12, Trelleborg Hospital, Hedvägen 46, 23185 Trelleborg, Sweden

${ }^{2}$ Technical University of Denmark, Department of Electrical Engineering

Ørsteds Plads, Building 349, 2800 Kgs. Lyngby, Denmark

${ }^{3}$ Department of Biomedical Sciences, Division of Renal and Vascular Physiology, University

of Copenhagen, Copenhagen, Denmark

Short title:

Renal vascular $\mathrm{K}^{+}$-channels

Address for correspondence:

Charlotte Mehlin Sorensen

University of Copenhagen

Department of Biomedical Sciences, 10.5

Blegdamsvej 3

DK-2200 Copenhagen N

Denmark

Phone: +4535327404

E-mail: cmehlin@ sund.ku.dk

This article has been accepted for publication and undergone full peer review but has not been through the copyediting, typesetting, pagination and proofreading process, which may lead to differences between this version and the Version of Record. Please cite this article as doi: 10.1111/apha.12882

This article is protected by copyright. All rights reserved. 


\section{Abstract}

The control of renal vascular tone is important for the regulation of salt and water balance, blood pressure and the protection against damaging elevated glomerular pressure. The $\mathrm{K}^{+}$ conductance is a major factor in the regulation of the membrane potential $\left(\mathrm{V}_{\mathrm{m}}\right)$ in vascular smooth muscle (VSMC) and endothelial cells (EC). The vascular tone is controlled by $\mathrm{V}_{\mathrm{m}}$ via its effect on the opening probability of voltage operated $\mathrm{Ca}^{2+}$ channels (VOCC) in VSMC. When $\mathrm{K}^{+}$conductance increases $\mathrm{V}_{\mathrm{m}}$ becomes more negative and vasodilation follows, while deactivation of $\mathrm{K}^{+}$channels leads to depolarization and vasoconstriction. $\mathrm{K}^{+}$channels in $\mathrm{EC}$ indirectly participate in the control of vascular tone by endothelium derived vasodilation.

Therefore, by regulating the tone of renal resistance vessels, $\mathrm{K}^{+}$channels have a potential role in the control of fluid homeostasis and blood pressure as well as in the protection of the renal parenchyma. The main classes of $\mathrm{K}^{+}$channels (calcium activated $\left(\mathrm{K}_{\mathrm{Ca}}\right)$, inward rectifier $\left(\mathrm{K}_{\mathrm{ir}}\right)$, voltage activated $\left(\mathrm{K}_{\mathrm{v}}\right)$ and ATP sensitive $\left(\mathrm{K}_{\mathrm{ATP}}\right)$ ) have been found in the renal vessels. In this review, we summarize results available in the literature and our own studies in the field. We compare the ambiguous in vitro and in vivo results. We discuss the role of single types of $\mathrm{K}^{+}$ channels and the integrated function of several classes. We also deal with the possible role of renal vascular $\mathrm{K}^{+}$channels in the pathophysiology of hypertension, diabetes mellitus and sepsis.

Keywords: vasodilation, vasoconstriction, afferent arteriole, in vivo, in vitro, RVR, RBF

\section{Introduction}

The control of renal vascular tone has a dual purpose. Firstly, it participates in the regulation of renal blood flow (RBF) and glomerular filtration rate (GFR). Since the renal excretion of $\mathrm{Na}^{+}$and water is controlled by GFR and tubular reabsorption, the renal vascular tone is crucial for the maintenance and regulation of body fluid volume and blood pressure. Secondly, it has a protective function by governing intra-glomerular pressure. The importance of this function is illustrated by the renal microvascular and glomerular damage in several diseases among them hypertension and diabetes ${ }^{1,2}$. Thus, impaired renal vascular control could lead to rapid deterioration of arteriolar and glomerular tissue and decreased renal function eventually causing renal failure.

This article is protected by copyright. All rights reserved. 
As in other vascular beds, the constriction of renal vascular smooth muscle cells (VSMC) is controlled by the intracellular $\mathrm{Ca}^{2+}$ concentration $\left(\left[\mathrm{Ca}^{2+}\right]_{\mathrm{i}}\right)$ in parallel with $\mathrm{Ca}^{2+}$ independent mechanisms ${ }^{3}$. VSMC $\left[\mathrm{Ca}^{2+}\right]_{\mathrm{i}}$ is in turn determined by a balance between release and uptake from and to intracellular stores (e.g. the sarcoplasmatic reticulum) combined with entry from and efflux to the extracellular space.

Although $\mathrm{Ca}^{2+}$ entry via voltage independent $\mathrm{Ca}^{2+}$ channels may play a role in the regulation of renal vascular tone, the entry largely occurs via voltage-operated $\mathrm{Ca}^{2+}$ channels (VOCC) ${ }^{4}$, 5 . These channels are activated by depolarization of the VSMC cell membrane and are thus under control of the cell membrane potential $\left(\mathrm{V}_{\mathrm{m}}\right)$. The dominating VOCC in most vascular beds, among them renal, is the dihydropyridine sensitive L-type channel ( $\left.\mathrm{Ca}_{\vee} 1.2\right)^{3,6,7}$. Furthermore, T-type channels have been found in several vascular beds including renal preand postglomerular arterioles ${ }^{7-10}$ but their role is debated and remains to be fully elucidated ${ }^{8,}$ 11-13. As renal VSMC $\mathrm{V}_{\mathrm{m}}$ is mainly determined by $\mathrm{K}^{+}$channels in these cells, they may have an important impact on the salt and water balance and thus blood pressure. There are four main classes of vascular $\mathrm{K}^{+}$channels: calcium activated $\left(\mathrm{K}_{\mathrm{Ca}}\right)$, inward rectifier $\left(\mathrm{K}_{\mathrm{ir}}\right)$, voltage activated $\left(\mathrm{K}_{\mathrm{v}}\right)$, and ATP sensitive $\left(\mathrm{K}_{\mathrm{ATP}}\right)$. The $\mathrm{K} 2 \mathrm{P}$ channels are also found in the vasculature but their role is less explored ${ }^{14}$. $\mathrm{V}_{\mathrm{m}}$ is determined by the ion gradients and their relative conductances over the VSMC membrane. In addition, endothelial cells may affect VSMC $V_{m}$ via myoendothelial gap junctions ${ }^{15}$. Primarily, it is the intra- and extracellular concentrations of $\mathrm{K}^{+}, \mathrm{Na}^{+}$and $\mathrm{Cl}^{-}$ions and their membrane conductances that control $\mathrm{V}_{\mathrm{m}}$. Thus, $\mathrm{V}_{\mathrm{m}}$ can be derived from the chord conductance equation:

$$
\mathrm{V}_{\mathrm{m}}=\frac{\mathrm{E}_{\mathrm{K}} g_{\mathrm{K}}+\mathrm{E}_{\mathrm{Na}} g_{\mathrm{Na}}+\mathrm{E}_{\mathrm{Cl}} g_{\mathrm{Cl}}}{g_{\mathrm{K}}+g_{\mathrm{Na}}+g_{\mathrm{Cl}}}
$$

Here $E_{x}$ is the equilibrium potential for the specific ion $x$ and $g_{x}$ is its conductance. $E$ for the ion is calculated by the Nernst equation (here adjusted for body temperature, $37^{\circ} \mathrm{C}$, and converted to $\left.\log _{10}\right)$ :

$$
E_{\text {ion }} \approx \frac{61.5 \mathrm{mV}}{\mathrm{z}} \log \frac{[\text { ion }]_{\text {out }}}{[\text { ion }]_{\text {in }}}
$$

$\mathrm{z}$ is the valence of the particular ion.

This article is protected by copyright. All rights reserved. 
Significant changes in $\mathrm{V}_{\mathrm{m}}$ involve changes in conductances of $\mathrm{K}^{+}, \mathrm{Na}^{+}$and /or $\mathrm{Cl}^{-}$ions. $\mathrm{As} \mathrm{K}^{+}$ channels are the dominant cation channels in VSMC ${ }^{16} \mathrm{~V}_{\mathrm{m}}$ is largely determined by $\mathrm{E}_{\mathrm{K}}$. With normal extra- and intracellular concentrations of $\mathrm{K}^{+}$, calculated as above $\mathrm{E}_{\mathrm{K}}$ is $\sim-90 \mathrm{mV}$. Owing to the effect of the other ions involved, $\mathrm{V}_{\mathrm{m}}$ is more positive. Accordingly, $\mathrm{V}_{\mathrm{m}}$ of afferent arteriolar VSMC has been found to be between -55 and $-40 \mathrm{mV}$ at normal blood pressure ranges measured in hydronephrotic kidneys ${ }^{17-19}$. Membrane potentials in this range are close to the L-type $\mathrm{Ca}^{2+}$ channel activation potential but more positive than that for $\mathrm{T}$ type $\mathrm{Ca}^{2+}$ channels ${ }^{19,20}$.

Changes in $g_{K}$ thus affect the tone of the renal vessels. A decreased general $\mathrm{K}^{+}$conductance depolarizes the cell membrane inducing vasoconstriction. An increased $\mathrm{K}^{+}$conductance has the opposite effect ${ }^{21,22}$. In this review, we summarize the current literature on the role of $\mathrm{K}^{+}$ channels in the renal vasculature. We deal with studies investigating the integrated renal vascular bed as well as in vitro results originating from intra-renal arteries and arterioles. In addition, we discuss the possible interaction between several classes of $\mathrm{K}^{+}$channels in the control of renal vascular tone as well as the role of $\mathrm{K}^{+}$channels in the communication between endothelial cells (EC) and VSMC. The role of renal vascular $\mathrm{K}^{+}$channels in renovascular pathology is also discussed.

\section{Renal vascular $\mathrm{K}^{+}$channels}

The nomenclature for vascular $\mathrm{K}^{+}$channels used in this review is based on the International Union of Basic and Clinical Pharmacology (IUPHAR). Table 1 provides a comparison between the IUPHAR classification and the colloquial names for channels dealt with in this review. The $\mathrm{K}^{+}$channels are distributed into four subfamilies: 1 . Calcium activated $\left(\mathrm{K}_{\mathrm{Ca}}\right), 2$. Inwardly rectifying $\left(\mathrm{K}_{\mathrm{ir}}\right)$, 3. Voltage gated $\left(\mathrm{K}_{\mathrm{V}}\right)$, 4. Two-pore domain $(\mathrm{K} 2 \mathrm{P})$ channels. Based on their permeability, $\mathrm{K}_{\mathrm{Ca}}$ channels are further subdivided into large, intermediate and small conductance calcium-activated potassium channels $\left(\mathrm{BK}_{\mathrm{Ca}}, \mathrm{IK}_{\mathrm{Ca}}\right.$ and $\mathrm{SK}_{\mathrm{Ca}}$, respectively). The $\mathrm{K}_{\mathrm{ATP}}$ channels are composed of $\mathrm{K}_{\mathrm{ir}} 6.1$ or $\mathrm{K}_{\mathrm{ir}} 6.2$ subunits and thus they belong to the inward rectifier super family ${ }^{23}$. To our knowledge, the possible significance of K2P channels in the renal vasculature has never been investigated. However, considering the diversity of $\mathrm{K}^{+}$channels, it is highly possible that classes of $\mathrm{K}^{+}$channels which have not yet been described in the renal vasculature participate in the regulation of renal hemodynamics ${ }^{24}$.

This article is protected by copyright. All rights reserved. 


\section{$\mathrm{K}^{+}$channels in renal vascular smooth muscle}

$B K_{C a}$ channels in VSMC

The conductance of $\mathrm{BK}_{\mathrm{Ca}}$ channels is in the range of $100-200 \mathrm{pS}^{25-27}$. In addition to their $\mathrm{Ca}^{2+}$ - sensitivity, they are also sensitive to electrical potential ${ }^{25}$. At negative membrane potentials $\left(-50\right.$ to $-70 \mathrm{mV}$ ) close to normal resting potentials measured in vivo in VSMC ${ }^{28}$, activation is reported to require intracellular $\left[\mathrm{Ca}^{2+}\right]$ in the range of $1-10 \mu \mathrm{M}^{29,30}$. Therefore, it is not totally clarified to what extent $\mathrm{BK}_{\mathrm{Ca}}$ channels contribute to the normal resting $\mathrm{V}_{\mathrm{m}}{ }^{29}$. Physiologically, $\mathrm{BK}_{\mathrm{Ca}}$ may be modulated by protein kinases. Although there are a few exceptions ${ }^{31}$, most reports indicate that they are activated by protein kinase $\mathrm{A}^{32}$ and/or $\mathrm{G}^{33}$, ${ }^{34}$ (PKA and PKG, respectively; Fig. 2) and inhibited by protein kinase C (PKC; Fig. 1) ${ }^{35,36}$. Nitric oxide (NO) stimulates the PKG pathway. Therefore activation of the NO system potentially may lead to increased activity of $\mathrm{BK}_{\mathrm{Ca}}$ channels (Fig. 2) ${ }^{37}$. Likewise, it is suggested that vasoconstrictors could act via PKC mediated inhibition of $\mathrm{BK}_{\mathrm{Ca}}$ channels (Fig. 1) ${ }^{35,36} . \mathrm{BK}_{\mathrm{Ca}}$ channels are pharmacologically inhibited by tetraethylammonium (TEA), charybdotoxin or more specifically by iberiotoxin. They are stimulated by NS $1619^{38}$.

\section{Function}

$\mathrm{BK}_{\mathrm{Ca}}$ channels may have a buffering function on vasoconstrictor responses (Fig. 1) ${ }^{39}$. The depolarization and increase in VSMC $\left[\mathrm{Ca}^{2+}\right]_{i}$, resulting from agonist stimulation or myogenic activation activates $\mathrm{BK}_{\mathrm{Ca}}$ channels, initiating a hyperpolarizing current that attenuates depolarization and opposes vasoconstriction ${ }^{40}$. There is evidence that a complex formed by $\mathrm{BK}_{\mathrm{Ca}}$ channels and VOCC might provide a basis for the control of $\mathrm{BK}_{\mathrm{Ca}}$ channel activation ${ }^{41}$. Accordingly, in several vascular beds it is shown that $\mathrm{BK}_{\mathrm{Ca}}$ channels open simultaneously with the L-type $\mathrm{Ca}^{2+}$ channels ${ }^{29,42}$. Furthermore, ryanodine-sensitive $\mathrm{Ca}^{2+}$ release from intracellular stores may also buffer vasoconstriction via $\mathrm{BK}_{\mathrm{Ca}}$ channel activation ${ }^{43}$.

\section{Renal function}

We and others have found evidence for the expression of $\mathrm{BK}_{\mathrm{Ca}}$ channels in rat preglomerular vessels utilizing RT-PCR and immunofluorescence ${ }^{44,45}$. Their presence has also been suggested in rat mesangial cells and an iberiotoxin sensitive current has been identified in rat juxtaglomerular cells 45 46, 47 .

TEA is reported to induce an elevated basal perfusion pressure in the isolated perfused rat kidney which suggests that $\mathrm{BK}_{\mathrm{Ca}}$ channels contribute to the basal renal vascular tone. ${ }^{48,49}$. These results should be interpreted with caution as the TEA concentration used in these studies were between 2 and $10 \mathrm{mM}$, concentrations where TEA is not specific for the $\mathrm{BK}_{\mathrm{Ca}}$

This article is protected by copyright. All rights reserved. 
channel but is reported to also inhibit both $\mathrm{K}_{\mathrm{v}}$ channels and $\mathrm{K}_{\mathrm{ATP}}$ channels ${ }^{50,51}$. Nevertheless, a lower concentration of TEA $(1 \mathrm{mM})$ has been reported to constrict the afferent arteriole using the blood perfused juxtamedullary nephron preparation ${ }^{52,53}$. Using the same technique it was shown that stimulation with the $\mathrm{BK}_{\mathrm{Ca}}$ channel opener NS $1619(30 \mu \mathrm{M})$ increased afferent arteriolar diameter, an effect that was abolished by TEA $(1 \mathrm{mM}){ }^{54}$. At these concentrations the authors assumed NS 1619 and TEA to be specific for the $\mathrm{BK}_{\mathrm{Ca}}$ channels. It should, however, be kept in mind that even at these concentrations NS 1619 and TEA has been shown to affect $\mathrm{K}_{\mathrm{V}}$ channels ${ }^{55-58}$. We found that TEA, at an estimated plasma concentration of $1 \mathrm{mM}$ infused directly into the rat renal artery in vivo reduced baseline RBF by $\sim 10 \%$. Meanwhile the more specific $\mathrm{BK}_{\mathrm{Ca}}$ channel blocker iberiotoxin, at an estimated plasma concentration of $100 \mathrm{nM}$, had no effect ${ }^{44}$. Furthermore, we found that NS 1619 (estimated plasma concentration $30 \mu \mathrm{M}$ ) had no effect on rat RBF in vivo ${ }^{44}$. These results indicate a limited role for $\mathrm{BK}_{\mathrm{Ca}}$ channels in the regulation of renal vascular tone under resting conditions in vivo and are in contrast to the in vitro results emanating from the blood perfused juxtamedullary nephron preparation. The discrepancy between the in vivo and the in vitro studies might be explained by different $\left[\mathrm{Ca}^{2+}\right]_{i}$ or $\mathrm{Ca}^{2+}$-sensitivity. The effect of NS 1619 is $\mathrm{Ca}^{2+}$ dependent and it is possible that in vivo $\left[\mathrm{Ca}^{2+}\right]_{\mathrm{i}}$ in renal VSMC is not sufficient to allow activation by $\mathrm{NS}_{1619}{ }^{38}$. Thus, it is unclear whether $\mathrm{BK}_{\mathrm{Ca}}$ channels have a role in the maintenance of the normal resting potential of renal VSMC and therefore in renal vascular tone.

\section{Renal buffer function}

As in Fallet et al. ${ }^{54}$, we found that renal vasoconstriction induced by Ang II in vivo was impaired by NS $1619^{44}$. The effect was reversed by TEA and iberiotoxin indicating that the attenuation is caused by stimulation of $\mathrm{BK}_{\mathrm{Ca}}$ channels. Possibly the elevated $\left[\mathrm{Ca}^{2+}\right]_{\mathrm{i}}$ under Ang II stimulation facilitates the action of NS 1619. The attenuating effect of NS 1619 on the ANG II responses indicates that the renal $\mathrm{BK}_{\mathrm{Ca}}$ channels may have a buffering function on vasoconstrictor responses (Fig. 1). The activation of $\mathrm{BK}_{\mathrm{Ca}}$ channels may also play a role in renal vasodilation. However, TEA and iberiotoxin did not augment the juxtamedullary afferent arteriolar diameter reduction in vitro or in vivo in response to vasoconstrictors ${ }^{44,54}$. On the other hand Loutzenhiser \& Parker found that TEA elevated myogenic response of afferent arterioles which indicates that renal myogenic vasoconstriction might be buffered by opening of $\mathrm{BK}_{\mathrm{Ca}}$ channels ${ }^{59}$.

This article is protected by copyright. All rights reserved. 
Activation of adenylate or guanylate cyclase and subsequent increases in cAMP or cGMP, respectively, followed by increased kinase activity may induce activation of $\mathrm{BK}_{\mathrm{Ca}}$ channels and vasodilation ${ }^{33,60}$. We did not find support in vivo for cAMP stimulation of $\mathrm{BK}_{\mathrm{Ca}}$ channels leading to vasodilation. Renal vasodilation induced by forskolin, an activator of adenylate cyclase, was not affected by iberiotoxin in rats ${ }^{44}$. However, cAMP stimulates several other $\mathrm{K}^{+}$-channels. We cannot exclude the possibility that the vasodilation was caused by activation of several classes of these channels, including $\mathrm{BK}_{\mathrm{Ca}}$ channels. $\mathrm{BK}_{\mathrm{Ca}}$ channel $\beta$-subunits contribute to a large diversity in $\mathrm{BK}_{\mathrm{Ca}}$ channel function. Mice lacking the subunit Mbeta1 are mildly hypertensive. During acute volume expansion, the increase in GFR seen in wild type mice was decreased in the Mbeta1-/- mice indicating a role for the beta1-subunit of $\mathrm{BK}_{\mathrm{Ca}}$ channels in the renal vasodilatory response to acute volume loading 6162 .

NO causes renal vasodilation and based on studies on isolated VSMC from rat preglomerular vessels, it is suggested that activation of $\mathrm{BK}_{\mathrm{Ca}}$ channels may be involved. It was shown that the $\mathrm{NO}$ donor sodium nitroprusside reduced the increase in $\left[\mathrm{Ca}^{2+}\right]_{\mathrm{i}}$ in response to $50 \mathrm{mM} \mathrm{KCl}$ and that iberiotoxin reestablished this response ${ }^{63}$. This suggests a role for $\mathrm{BK}_{\mathrm{Ca}}$ channels in NO induced renal vasodilation. On the other hand, it is somewhat challenging to comprehend how activation of $\mathrm{BK}_{\mathrm{Ca}}$ channels would cause sufficient hyperpolarization to inactivate VOCC in the presence of $50 \mathrm{mM} \mathrm{KCl}$. Nernst's equation show that $\mathrm{E}_{\mathrm{K}}$ in this condition is much more positive than the activation level of L-type VOCC. As opening of $\mathrm{BK}_{\mathrm{Ca}}$ channels would not cause $\mathrm{V}_{\mathrm{m}}$ to become more negative than $\mathrm{E}_{\mathrm{K}}$, a substantial effect on VOCC activity cannot be predicted. In addition, TEA has only a slight effect on the afferent arteriolar vasodilation in response to acetylcholin (ACh) as shown in the perfused hydronephrotic rat kidney ${ }^{64}$. This finding does not support a $\mathrm{BK}_{\mathrm{Ca}}$ channel mediated NO induced renal vasodilation as the $\mathrm{ACh}$ response is largely mediated by $\mathrm{NO}^{64-66}$. On the other hand, $\mathrm{BK}_{\mathrm{Ca}}$ channels may mediate the effect of other vasodilators. Epoxyeicosatrienoic acid (EET), which has been suggested to participate in endothelial derived hyperpolarization (EDH), causes afferent arteriolar vasodilation that is inhibited by iberiotoxin, indicating a role for $\mathrm{BK}_{\mathrm{Ca}}$ channels in this setting ${ }^{67}$ (Fig. 2). It has also been suggested that EETs may mediate the afferent arteriolar vasodilation induced by bradykinin via activation of $\mathrm{BK}_{\mathrm{Ca}}$ channels ${ }^{68}$. In summary, renal $\mathrm{BK}_{\mathrm{Ca}}$ channels do not seem to affect renal vascular resistance in vivo even though in vitro results suggests this. $\mathrm{BK}_{\mathrm{Ca}}$ channels do however seem to act as buffers in response to agonist- or pressure induced vasoconstriction.

This article is protected by copyright. All rights reserved. 
$I K_{C a}$ and $S K_{C a}$ channels in VSMC

Only few studies suggest the presence of $\mathrm{IK}_{\mathrm{Ca}}$ and $\mathrm{SK}_{\mathrm{Ca}}$ channels in renal VSMC. One study shows the presence of an apamin-sensitiv $\mathrm{K}^{+}$channel with a conductance of $68 \mathrm{pS}$ in VSMC isolated from preglomerular arterioles ${ }^{69}$. However, functional evidence for a role in regulation of renal blood flow is lacking. In the isolated blood perfused juxtamedullary nephron preparation no change in afferent arteriolar diameter was seen after treatment with $100 \mathrm{nM}$ apamin ${ }^{52}$ and intrarenal infusion of apamin $(0.5 \mu \mathrm{M})$ had no effect on RBF in vivo 10 .

\section{$K_{\text {ir }}$ channels in VSMC}

The single channel conductance of the classic $\mathrm{K}_{\mathrm{ir}}$ channel $\left(\mathrm{K}_{\mathrm{ir}} 2\right)$ is $\sim 20 \mathrm{pS}^{16}$. In the vascular system, $\mathrm{K}_{\mathrm{ir}}$ channels predominantly reside in VSMC from microvessels where the main isoform is $\mathrm{K}_{\mathrm{ir}} 2.1^{70-73}$. They are named "inward rectifier" channels since they carry larger inward (at potentials negative to $E_{K}$ ) than outward currents $K_{i r}$ (Fig. 3). As $V_{m}$ is more positive than $\mathrm{E}_{\mathrm{K}}$ under physiological conditions, $\mathrm{K}_{\mathrm{ir}}$ channels carry a small outward hyperpolarizing $\mathrm{K}^{+}$current ${ }^{74}$. This current is sensitive to extracellular $\mathrm{K}^{+}$concentration $\left(\left[\mathrm{K}^{+}\right]_{\mathrm{o}}\right)^{75}$. A small increase $(\sim 5-12 \mathrm{mM})$ in $\left[\mathrm{K}^{+}\right]_{\mathrm{o}}$ increases the outward current at membrane potentials measured in afferent arteriolar VSMC ${ }^{17}$ (Fig. 3). The mechanism might be mediated by interaction of $\mathrm{K}^{+}$ions with polyamines or $\mathrm{Mg}^{2+}$ in the channel pore causing increased opening probability ${ }^{76,77}$. When $\left[\mathrm{K}^{+}\right]_{\mathrm{o}}$ is increased to $>\sim 20 \mathrm{mM}$, the depolarizing effect of the increased $\left[\mathrm{K}^{+}\right]_{\mathrm{o}}$, according to the Nernst equation, becomes dominant and the net effect is depolarization. $\mathrm{K}_{\mathrm{ir}}$ channels may also function as an amplifier of hyperpolarization if $\mathrm{V}_{\mathrm{m}}$ becomes more hyperpolarized and thus reaches a voltage range with larger conductance and thus elevated outward current ${ }^{78-81}$. At concentrations lower than $100 \mu \mathrm{M}, \mathrm{Ba}^{2+}$ is considered to be specific for $\mathrm{K}_{\mathrm{ir}}$ channels with a reported half maximal inhibition concentration of $2.2 \mu \mathrm{M}$ at $-60 \mathrm{mV}^{82}$.

\section{Function}

As $\mathrm{K}_{\mathrm{ir}}$ channels are sensitive to small elevations in $\left[\mathrm{K}^{+}\right]_{\mathrm{o}}$, they may participate in $\mathrm{K}^{+}$induced vasodilation as a part of the metabolic regulation of blood flow ${ }^{83-85}$. Furthermore, they may have a role in the $\mathrm{EDH}$ response via $\mathrm{K}^{+}$released from endothelial $\mathrm{IK}_{\mathrm{Ca}}$ and $\mathrm{SK}_{\mathrm{Ca}}$ channels (Fig. 2) ${ }^{86}$. It is possible that part of the $\mathrm{K}^{+}$induced hyperpolarization/vasodilation is mediated by activation of $\mathrm{Na} / \mathrm{K}$ ATPase ${ }^{87}$.

This article is protected by copyright. All rights reserved. 


\section{Renal function}

In the renal vasculature, $\mathrm{K}_{\mathrm{ir}} 2.1$ channels are expressed in both VSMC and EC of rat afferent and efferent arterioles ${ }^{88,89}$. In the rat descending vasa recta, both the endothelial cells and the pericytes express $\mathrm{K}_{\mathrm{ir}} 2.1, \mathrm{~K}_{\mathrm{ir}} 2.2$, and $\mathrm{K}_{\mathrm{ir}} 2.3$ channels ${ }^{90,91}$. $\mathrm{K}_{\mathrm{ir}}$ currents have been identified in the afferent and efferent arterioles and the distal rat interlobular artery (ILA) while they are absent in the proximal part of the same vessel ${ }^{90,92-94}$.

At concentrations supposed to be specific for $\mathrm{K}_{\mathrm{ir}}$ channels $(\leq 100 \mu \mathrm{M}), \mathrm{Ba}^{2+}$ reduced afferent arteriolar diameter ${ }^{18}$. Likewise renal vascular resistance (RVR) was increased in isolated perfused kidneys after $\mathrm{Ba}^{2+}$ treatment ${ }^{48}$. We found that infusion of $\mathrm{Ba}^{2+}$ into the rat renal artery, at an estimated final plasma concentration of $20 \mu \mathrm{M}$, caused a small (6-13\%) transient elevation of baseline RVR in vivo ${ }^{89}$. These studies indicate a role for $\mathrm{K}_{\mathrm{ir}}$ channels in the basal RVR.

\section{$K^{+}$induced renal vasodilation}

An increase in plasma $\left[\mathrm{K}^{+}\right]$has been reported to decrease RVR, increase GFR, urine flow and $\mathrm{Na}^{+}$excretion in several species ${ }^{95-97,98}$. These findings are in accord with the notion of a $\mathrm{K}^{+}$ induced renal vasodilation ${ }^{97}$. It is possible that such a mechanism is relevant when plasma $\mathrm{K}^{+}$ increases following metabolic stress where $\mathrm{K}^{+}$induced renal vasodilation may have a protective function. As high dietary $\mathrm{K}^{+}$is correlated with a decreased risk for cardiovascular disease it may also be speculated that the slightly increased plasma $\left[\mathrm{K}^{+}\right]$that follows high $\mathrm{K}^{+}$ intake mediates renal vasodilation and decreased arterial blood pressure via stimulation of renal vascular $\mathrm{K}_{\mathrm{ir}}$ channels ${ }^{97,99}$. In this regard it is interesting that small physiologic changes in $\mathrm{K}^{+}$concentration have been reported to participate in the control of renal medullary blood flow via $K_{\text {ir }}$ channels located in vasa recta ${ }^{90,91}$.

The $\mathrm{K}^{+}$induced renal vasodilation may be caused by activation of either $\mathrm{Na}^{+} / \mathrm{K}^{+}$-ATPase or $\mathrm{K}_{\mathrm{ir}}$ channels with subsequent VSMC hyperpolarization ${ }^{18,88,100} . \mathrm{K}^{+}$induced vasodilation of afferent arterioles was blocked by $\mathrm{Ba}^{2+18,88}$. In the larger rabbit, arcuate artery vasodilation was blocked by ouabain, an inhibitor of the $\mathrm{Na}^{+} / \mathrm{K}^{+}$-ATPase ${ }^{100}$. This is in line with the notion of a more pronounced activity for $\mathrm{K}_{\mathrm{ir}}$ channels in smaller vessels. Chilton et al. have shown that the $\mathrm{K}^{+}$induced vasodilation of the interlobular artery was correlated to vessel diameter ${ }^{92}$. The distal interlobular artery (ILA) dilated in response to $15 \mathrm{mM} \mathrm{K}^{+}$while this response was absent in the proximal ILA. The response was inhibited by $100 \mu \mathrm{M} \mathrm{Ba}^{2+}$ but not by ouabain ${ }^{92}$. Different results might be obtained when the integrated response of the intact renal circulation is under investigation. Accordingly, in isolated perfused rat kidneys, $\mathrm{Ba}^{2+}$ or ouabain attenuated the $\mathrm{K}^{+}$induced renal vasodilation. This indicates a role for both

This article is protected by copyright. All rights reserved. 
$\mathrm{K}_{\mathrm{ir}}$ channels and $\mathrm{Na} / \mathrm{K}$ ATPase in this process ${ }^{97}$. Our laboratory has confirmed this in vivo in normotensive rats while the effect of ouabain was not significant in hypertensive rats ${ }^{89}$.

\section{Voltage-gated $K^{+}$channels in VSMC}

Voltage-gated $\mathrm{K}^{+}\left(\mathrm{K}_{\mathrm{V}}\right)$ channels exhibit conductances between $\sim 4$ and $70 \mathrm{pS}$ depending on subtype, preparation and experimental conditions ${ }^{16,101-104}$. They are strongly voltage dependent and cell membrane depolarization leads to activation of $K_{V}$ channels (Fig. 1) and thus an increased hyperpolarizing outward $\mathrm{K}^{+}$current that deactivates VOCC channels and consequently decreases VSMC tone ${ }^{16,39,85,105}$ (Fig. 2).

\section{Function}

$\mathrm{K}_{\mathrm{V}}$ channels may contribute to the regulation of resting membrane potential by buffering membrane depolarization to maintain resting vascular tone ${ }^{39}$. In addition to the classical 4aminopyridine (4-AP) sensitive $\mathrm{K}_{\mathrm{V}} 1.1$ - 1.7 channels, $\mathrm{K}_{\mathrm{V}} 7$ channels have recently been described in VSMC from several vascular beds among them renal ${ }^{106-112}$. Prolonged depolarization leads to inactivation of $\mathrm{K}_{\mathrm{V}}$ channels which is a slower process than that of activation. Thus, the steady state current via these channels is determined by the balance between activation and inactivation ${ }^{16,34,39,113,114}$. Like other $\mathrm{K}^{+}$channels, $\mathrm{K}_{\mathrm{V}} 1$.x channels are activated by the cAMP/PKA and cGMP/PKG pathway ${ }^{15,116}$ (Fig. 2) and the activity is reduced by PKC (Fig. 1) ${ }^{36,117-120}$. Specifically, it is reported that PKA increases open probability of 4-AP sensitive single channels ${ }^{119}$.

In contrast to the 4-AP sensitive channels which are activated at $-20 \mathrm{mV}$, the $\mathrm{K}_{\mathrm{V}} 7$ channels, which are insensitive to 4-AP, activate at a more negative membrane potential. This potential is in the range of the resting membrane potential of renal arteriolar VSMC (-60 mV to -40 $\mathrm{mV})^{17,121,122}$. It is therefore likely that the physiological role of $\mathrm{K}_{\mathrm{V}} 7$ channels is different from that of the 4-AP sensitive $\mathrm{K}_{\mathrm{V}}$ channels. $\mathrm{K}_{\mathrm{V}} 7$ channels could have a larger impact on normal resting potential while $\mathrm{K}_{\mathrm{V}} 1$ channels may exhibit more of a buffering function ${ }^{85,122}$. $\mathrm{K}_{\mathrm{V}}$ 7.x channels are pharmacologically inhibited by XE991 or linordipine and $\mathrm{K}_{\mathrm{V}}$ 7.2-5 channels are stimulated by flupirtine or retigabine ${ }^{122,123}$.

\section{Renal function}

We and others have identified the expression of Kv1.2 and Kv1.4 channels in rat interlobar and arcuate arteries ${ }^{124}$ and $\mathrm{K}_{\mathrm{V}} 1.4$ channels in rat and mice afferent arteriolar VSMC ${ }^{10}$. Using patch clamp, 4-AP sensitive currents have been detected in VSMC from rat renal arcuate and interlobar arteries ${ }^{114,125}$. However, in rabbit arcuate arteries $\mathrm{K}_{\mathrm{V}}$ channels did not

This article is protected by copyright. All rights reserved. 
participate in maintenance of normal tone but seemed to have a buffering effect against depolarization in these vessels ${ }^{126}$. An intermediate conductance $\mathrm{K}^{+}$current sensitive to 4-AP has been reported in VSMC from rat preglomerular vessels ${ }^{127}$. Furthermore, a functional role for 4-AP sensitive $\mathrm{K}_{\mathrm{V}}$ channels has been suggested based on studies in the blood perfused juxtamedullary nephron preparation ${ }^{52}$ or the isolated perfused rat kidney ${ }^{48}$. In both these studies, 4-AP induced renal vasoconstriction.

$\mathrm{K}_{\mathrm{V}} 7$ channels have been found in the rat renal artery and in the isolated perfused rat kidney ${ }^{112}$. In that study it was found that linopirdine contracted isolated rat renal arteries. This is in accord with a recent report from our laboratory ${ }^{111}$. Using imunofluorescence, we revealed the expression of $\mathrm{K}_{\mathrm{V}} 7.4$ channels in rat afferent arterioles. Our results also pointed to a role for these channels in the maintenance of basal RVR. Namely, intrarenal XE991administration led to a reduction of rat RBF in vivo as well as a reduction in mouse afferent arteriolar diameter as assessed by the blood perfused juxtamedullary nephron technique. These effects were abolished by nifedipine indicating that inhibition of $\mathrm{K}_{\mathrm{V}} 7$ channels led to depolarization and activation of L-type $\mathrm{Ca}^{2+}$ channels. In addition flupirtine caused relaxation of isolated rat interlobar arteries in the wire myograph as well as an increase of RBF in vivo. In chronically instrumented conscious rats, retigabine caused transient renal vasodilatation in normotensive rats. This effect was augmented after Ang II induced acute hypertension ${ }^{128}$. These findings suggest a therapeutic potential for $\mathrm{K}_{\mathrm{V}} 7$ channel stimulation in the treatment of unfavorable renal vasoconstriction in vascular disease states.

\section{Renal buffer function}

In addition to contributing to the basal renal tone, it was found that $\mathrm{K}_{\mathrm{V}} 7$ channels partly mediate $\beta$-adrenoceptor-mediated renal vasodilation ${ }^{112}$. Furthermore, the RBF responses to the renal vasoconstrictors NE or Ang II were not affected by pretreatment with XE991 or flupirtine ${ }^{111}$. Surprisingly, XE991 pretreatment caused a minor augmentation of the ACh induced increase in RBF. Thus, $\mathrm{K}_{\mathrm{V}} 7$ channels do not seem to mediate or buffer agonist induced renal vasoconstriction or vasodilation.

\section{ATP-sensitive $K^{+}$channels in VSMC}

The ATP-sensitive $\mathrm{K}^{+}$channel $\left(\mathrm{K}_{\mathrm{ATP}}\right)$ comprises four transmembrane domains emanating from the $\mathrm{K}_{\text {ir }}$ channel family (Kir6.1 or Kir6.2; table 1) which forms the pore, and four additional subunits of sulfonylurea receptors (SUR1, SUR2A and SUR2B) exhibiting a regulatory function ${ }^{23}$. The single channel conductance for $\mathrm{K}_{\mathrm{ATP}}$ channels shows a substantial 
variation between different tissues as values from $15 \mathrm{pS}$ to $258 \mathrm{pS}$ have been reported for VSMC $^{23,39,129}$. These channels are inhibited physiologically by elevated intracellular ATP (Fig. 1) and stimulated by ADP ${ }^{39}$. As the ATP/ADP ratio regulates their activity, they have the potential to adapt the vascular tone to the metabolic needs of the tissue ${ }^{130}$. In addition, they are stimulated by PKA (Fig. 2) and/or PKG and inhibited by PKC ${ }^{16,85}$.

Pharmacologically, they are inhibited by sulfonylureas such as glibenclamide and stimulated by drugs such as cromakalim, pinacidil and diazoxide ${ }^{131}$.

\section{Renal function}

Lorenz et al. found a $\mathrm{K}^{+}$channel in rabbit afferent arteriolar myocytes with an unusually high conductance $(258 \mathrm{pS})$ which was inactivated by $1 \mathrm{mM} \mathrm{ATP}{ }^{129}$. The authors also reported that the $\mathrm{K}_{\mathrm{ATP}}$ channel opener diazoxide dilated rabbit isolated afferent arterioles in vitro while these vessels were constricted by the $\mathrm{K}_{\mathrm{ATP}}$ channel inhibitor glibenclamide ${ }^{129}$. Binding studies and in situ hybridization histochemistry have revealed the existence of $\mathrm{K}_{\mathrm{ATP}}$ channels in smaller rat renal arteries and arterioles ${ }^{132}$.

Jensen et al. found in the isolated perfused rat kidney that cromakalim caused a renal vasodilation that was attenuated by glibenclamide ${ }^{133}$. It has also been shown, using the blood-perfused juxtamedullary nephron preparation, that pinacidil caused afferent arteriolar vasodilation whereas glibenclamide had little effect on afferent arteriolar tone ${ }^{134}$. Several in vivo studies have found that different $\mathrm{K}_{\mathrm{ATP}}$ channel stimulators increase $\mathrm{RBF}$ in rats and dogs ${ }^{135-139}$ whereas glibenclamide had no effect on RBF in rats ${ }^{10}$. $\mathrm{K}_{\mathrm{ATP}}$ channels and glibenclamide sensitive currents has also been described in the rat descending vasa recta ${ }^{140}$.

\section{Metabolic vasodilation}

Lowered glucose concentrations led to vasodilation in isolated rabbit afferent arterioles, an effect that was reversed by glibenclamide. This supports the notion of regulation of renal blood flow by intracellular levels of ATP ${ }^{129}$. Furthermore, glibenclamide constricted while pinacidil dilated afferent arterioles from rats with streptozotocin-induced diabetes implicating $\mathrm{K}_{\mathrm{ATP}}$ channels in the hyperfiltration seen in diabetes ${ }^{134}$.

It has also been suggested that $\mathrm{K}_{\mathrm{ATP}}$ channels mediate the vasomotor response to changes in oxygen tension in different vascular beds ${ }^{21,130}$. The rat afferent arteriolar myogenic response was attenuated via activation of $\mathrm{K}_{\mathrm{ATP}}$ by low oxygen tension $\left(\mathrm{PO}_{2} 20 \mathrm{~mm} \mathrm{Hg}\right)$. This myogenic response was restored by glibenclamide ${ }^{59}$. These findings suggest that $\mathrm{K}_{\mathrm{ATP}}$ channels have a function in the adaptation of renal perfusion to hypoxia. As the cortex

This article is protected by copyright. All rights reserved. 
normally has a low arterio-venous $\mathrm{PO}_{2}$ difference, one could speculate that this mechanism is more important in the medullary circulation with its lower oxygen tension.

Based on results obtained in the perfused hydronephrotic rat kidney, it is suggested that afferent arteriolar vasodilation induced by calcitonin gene-related peptide (CGRP) or activation of $\mathrm{A} 2 \mathrm{a}$ adenosine receptors is mediated via activation of $\mathrm{K}_{\mathrm{ATP}}$ channels ${ }^{141,142}$.

\section{$\mathrm{K}^{+}$channels in renal endothelium}

$B K_{C a}$ channels in $E C$

$\mathrm{BK}_{\mathrm{Ca}}$ channels are present in endothelial cell of some vascular beds ${ }^{143,144}$. Hyperpolarization of $\mathrm{EC}$ following activation of $\mathrm{BK}_{\mathrm{Ca}}$ channels can increase the electrochemical gradient for $\mathrm{Ca}^{2+}$ thus increasing the $\mathrm{Ca}^{2+}$ influx to modulate NO production ${ }^{144-146}$. In addition, release of $\mathrm{K}^{+}$from endothelial $\mathrm{BK}_{\mathrm{Ca}}$ channels have been suggested to function as an endothelial derived hyperpolarizing factor (EDHF) by activation of $\mathrm{K}_{\mathrm{IR}}$ channels or $\mathrm{Na}^{+} / \mathrm{K}^{+}$-ATPases on VSMC 86,147 .

$B K_{C a}$ channels in renal EC

$\mathrm{BK}_{\mathrm{Ca}}$ channels have been identified in EC from renal arteries ${ }^{145}$ whereas expression in EC from smaller arteries was not confirmed ${ }^{44}$. A functional role in regulation of renal hemodynamics has not been shown.

\section{$S K_{C a}$ and $I K_{C a}$ channels in EC}

Small conductance potassium channels $\left(\mathrm{SK}_{\mathrm{Ca}}\right)$ and intermediate conductance potassium channels $\left(\mathrm{IK}_{\mathrm{Ca}}\right)$ have been found in most endothelial cells in the vasculature including the renal vasculature. The $\mathrm{IK}_{\mathrm{Ca}}$ and $\mathrm{SK}_{\mathrm{Ca}}$ channels are activated by increased $\left[\mathrm{Ca}^{2+}\right]_{\mathrm{i}}$ within the physiological range and they are not voltage sensitive ${ }^{148}$. The $\mathrm{SK}_{\mathrm{Ca}}$ and $\mathrm{IK}_{\mathrm{Ca}}$ channels have conductances of $10 \mathrm{pS}$ and $40 \mathrm{pS}$, respectively ${ }^{149,150}$. $\mathrm{SK}_{\mathrm{Ca}}$ channels are inhibited by apamin and the IK channels by TRAM-34 and the less specific charybdotoxin ${ }^{144,146}$. Both IK $_{\mathrm{Ca}}$ and $\mathrm{SK}_{\mathrm{Ca}}$ channels are stimulated by NS $309^{151}$.

$\mathrm{IK}_{\mathrm{Ca}}$ channels are mostly located in the vicinity of myoendothelial junctions (MEJ) whereas the $\mathrm{SK}_{\mathrm{Ca}}$ channels are distributed more evenly over the endothelial surface ${ }^{152-154}$. However, this distribution remains to be quantified in renal arteries and arterioles.

In endothelial cells, activation of $\mathrm{IK}_{\mathrm{Ca}}$ and $\mathrm{SK}_{\mathrm{Ca}}$ channel by $\mathrm{Ca}^{2+}$ involves activation of a $\mathrm{G}$ coupled receptor and an $\mathrm{IP}_{3}$ mediated increase in cytosolic $\mathrm{Ca}^{2+155} \cdot\left[\mathrm{Ca}^{2+}\right]_{\mathrm{i}}$ can also be modulated by the opening of endothelial TRP channels ${ }^{146,156}$. TRP channel activity has directly been linked to $\mathrm{IK}_{\mathrm{Ca}}$ opening in the MEJ ${ }^{157}$. It is suggested that the location of $\mathrm{IK}_{\mathrm{Ca}}$

This article is protected by copyright. All rights reserved. 
channels in the MEJ creates a signaling micro-domain that allows $\mathrm{Ca}^{2+}$ to be elevated only in the MEJ and thereby specifically activate the $\mathrm{IK}_{\mathrm{Ca}}$ channels here ${ }^{158,159}$.

$S K_{C a}$ and $I K_{C a}$ channels in renal EC

Endothelial $\mathrm{IK}_{\mathrm{Ca}}$ and $\mathrm{SK}_{\mathrm{Ca}}$ channels are expressed in the renal vasculature ${ }^{10,69}$. Apamininduced inhibition of $\mathrm{SK}_{\mathrm{Ca}}$ channels increases RVR in the isolated perfused kidney ${ }^{48}$. In contrast, it does not affect baseline rat afferent arteriolar diameter in the blood-perfused juxtamedullary model ${ }^{52}$ or RBF in anesthetized rats ${ }^{10}$.

\section{Renal EDH}

Endothelium derived hyperpolarization $(\mathrm{EDH})$ is defined as the endothelial mediated vasodilation elicited by $\mathrm{ACh}$ or bradykinin that remains when $\mathrm{NO}$ and prostacyclin production is inhibited ${ }^{160}$. The current generated by the activation of $\mathrm{IK}_{\mathrm{Ca}}$ and $\mathrm{SK}_{\mathrm{Ca}}$ channels is suggested to initiate a hyperpolarizing current into the VSMC via MEGJ. Furthermore, $\mathrm{IK}_{\mathrm{Ca}}$ and $\mathrm{SK}_{\mathrm{Ca}}$ channel activation may increase the $\mathrm{K}^{+}$concentration in the extracellular space between EC and VSMC. This in turn leads to activation of VSMC $\mathrm{K}_{\mathrm{ir}}$ channels and $\mathrm{Na}^{+} / \mathrm{K}^{+}-$ ATPases and to hyperpolarization of these cells ${ }^{15,86,161-163}$. The exact mechanisms behind EDH remain unclear and may depend on the vascular bed and the arterial segment ${ }^{160,164-166}$. This might explain some of the different results that have been obtained in vitro with renal arteries and arterioles ${ }^{43,61,137,167}$. Some have shown a major role of $\mathrm{IK}_{\mathrm{Ca}}$ and $\mathrm{SK}_{\mathrm{Ca}}$ channels in renal EDH whereas others have suggested a minor role. Boettcher et al ${ }^{168}$ showed that in a. gracilis under isometric conditions lack of connexin 40 reduced the EDH response whereas under isobaric conditions the EDH response was unaffected. This difference between isobaric and isometric setups might also provide an explanation for the discrepancy.

In the renal vasculature, in vitro studies have shown that the EDH-response can be abolished by co-treatment with apamin and charybdotoxin ${ }^{64,163,169}$. In the hydronephrotic rat kidney, Wang et al showed that inhibition of either the $\mathrm{IK}_{\mathrm{Ca}}$ or $\mathrm{SK}_{\mathrm{Ca}}$ channel with charybdotoxin or apamin respectively reduced the EDH response and a combination abolished the EDH response ${ }^{64,68}$. Under isometric conditions, we found that the EDH mediated vasodilation in rat renal interlobar arteries was inhibited by a combination of TRAM-34 and apamin. Also, inhibition of $\mathrm{Na}^{+} / \mathrm{K}^{+}$-ATPase and $\mathrm{K}_{\mathrm{ir}}$ channels reduced the magnitude of $\mathrm{EDH}{ }^{15}$. In vivo, the renal EDH is commonly quantified as changes in RBF. In wistar rats renal EDH was reduced when the $\mathrm{IK}_{\mathrm{Ca}}$ and $\mathrm{SK}_{\mathrm{Ca}}$ channels were inhibited with charybdotoxin and apamin ${ }^{170}$. In Sprague-Dawley rats we found that the EDH response was absent when inhibiting the $\mathrm{IK}_{\mathrm{Ca}}$ and $\mathrm{SK}_{\mathrm{Ca}}$ channels with a combination of TRAM-34 and apamin ${ }^{15}$. This suggests that $\mathrm{IK}_{\mathrm{Ca}}$ and $\mathrm{SK}_{\mathrm{Ca}}$ channels are crucial for renal $\mathrm{EDH}$, but that the complete mechanism is not 
clarified ${ }^{15}$. In contrast to the in vitro results, we found in vivo that inhibition of $\mathrm{Na}^{+} / \mathrm{K}^{+}-$ ATPase and $\mathrm{K}_{\mathrm{ir}}$ channels did not reduce the magnitude of $\mathrm{EDH}^{15}$.

$K_{\text {ir }}$ channels in EC

$\mathrm{K}_{\mathrm{ir}}$ channels are also found in $\mathrm{EC}^{171}$ where $\mathrm{K}_{\mathrm{ir}} 2.1$ seems to be the dominating isoform ${ }^{172}$. In renal vessels, $\mathrm{K}_{\mathrm{ir}}$ is found in EC in afferent and efferent arterioles ${ }^{88,89}$, in the renin-secreting cells ${ }^{94}$ and in the EC and pericytes of the decending vasa recta ${ }^{90,91}$. Inhibition of renal $\mathrm{K}_{\mathrm{ir}}$ channels induce vasoconstriction both in vitro ${ }^{18,48}$ and in vivo ${ }^{89}$ but whether this is caused by $\mathrm{K}_{\mathrm{ir}}$ channels expressed in EC or VSMC is hard to distinguish. In small mesenteric arteries, only EC express $\mathrm{K}_{\mathrm{ir}}$ and inhibition of these significantly reduces vasodilation in response to $\mathrm{ACh}^{173}$ and flow-induced vasodilation ${ }^{174}$.

\section{$K_{V}$ and $K_{A T P}$ channels in EC}

Although both $\mathrm{K}_{\mathrm{V}}$ and $\mathrm{K}_{\mathrm{ATP}}$ channels have been shown in EC, their exact role in regulation of renal vascular tone has not yet been clarified.

\section{Renal vascular $\mathrm{K}^{+}$channels in integrated renal hemodynamics.}

Several blockers of $\mathrm{K}^{+}$channels have a constrictor effect on renal vessels in vitro ${ }^{48}$ and in vivo ${ }^{10,89}$. Specifically $\mathrm{BK}_{\mathrm{Ca}}, \mathrm{K}_{\mathrm{ir}}, \mathrm{K}_{\mathrm{V}} 1, \mathrm{~K}_{\mathrm{V}} 7$ and $\mathrm{K}_{\mathrm{ATP}}$ channels have been shown to affect baseline renal vascular resistance in vitro whereas $K_{i r}, K_{V} 7$ and $K_{A T P}$ affect $R B F$ in vivo. However, the constrictor effect seems to be additive as blockage of a single group of channels elicits a smaller change than inhibition of several channels ${ }^{10,48}$ suggesting a considerable overlap in function. Closure of the $\mathrm{K}^{+}$channels causes depolarization of VSMC and opening of VOCC followed by vasoconstriction. Conversely, opening of $\mathrm{K}^{+}$channels leads to hyperpolarization and renal vasodilation. However, adding individual stimulators as well as a cocktail of $\mathrm{K}^{+}$channel openers in vivo only elicits minor effects on basal RBF, while the same cocktail attenuated the RBF responses to AngII and norepinephrine by $60 \%$ and $33 \%$, respectively ${ }^{10}$.

In the kidney, $\mathrm{BK}_{\mathrm{Ca}}$ channels in VSMC has been proposed to function as a buffer during agonist induced vasoconstriction ${ }^{27,35,36,85,126}$ (Fig. 1). In addition, the $\mathrm{BK}_{\mathrm{Ca}}$ channel opener NS 1619 attenuated Ang II induced reductions of RBF in vivo and this effect was reversed by iberiotoxin ${ }^{44}$. BK $\mathrm{Ca}$ channels also act as a buffer during the renal myogenic response ${ }^{59}$.

This article is protected by copyright. All rights reserved. 
As in other vascular beds, $\mathrm{SK}_{\mathrm{Ca}}$ and $\mathrm{IK}_{\mathrm{Ca}}$ channels in renal $\mathrm{EC}$ are suggested to induce endothelial derived hyperpolarization. This hyperpolarization can transfer to VSMC via myoendothelial gap junction. Furthermore, the $\mathrm{K}^{+}$released from $\mathrm{EC}$ via $\mathrm{SK}_{\mathrm{Ca}}$ and $\mathrm{IK}_{\mathrm{Ca}}$ channels can active $\mathrm{K}_{\mathrm{IR}}$ channels and $\mathrm{Na}^{+} / \mathrm{K}^{+}$-ATPases on VSMC to induce hyperpolarization and renal vasodilation. Renal $\mathrm{K}_{\mathrm{IR}}$ channels also play a role in $\mathrm{K}^{+}$induced vasodilation to elicit increases in RBF, GFR and sodium excretion possibly reducing arterial blood pressure during high potassium intake ${ }^{99}$.

Renal vessels express both $\mathrm{K}_{\mathrm{V}} 1$ and $\mathrm{K}_{\mathrm{V}} 7$ channels and $\mathrm{K}_{\mathrm{V}} 7$ are suggested to mediate $\beta$ adrenergic renal vasodilation.

Inactivation of several classes of $\mathrm{K}^{+}$channels might be mediated by $\mathrm{PKC}$ induced phosphorylation ${ }^{16,36,85,175}$. Blockade of PKC attenuates the Ang II or norepinephrine induced increase in afferent arteriolar VSMC $\left[\mathrm{Ca}^{2+}\right]_{\mathrm{i}}{ }^{176}$ suggesting that activation of PKC leads to depolarization via inhibition of $\mathrm{K}^{+}$channels ${ }^{4}$. In addition, renal afferent arteriolar myogenic activity is attenuated by PKC inhibition ${ }^{177}$. This effect was reversed by 4 -AP suggesting that PKC has an inhibitory effect on $\mathrm{K}_{\mathrm{V}}$ channels (Fig. 1). As PKC inhibits several other classes of $\mathrm{K}^{+}$channels, it is likely that $\mathrm{K}^{+}$channels other than $\mathrm{K}_{\mathrm{V}}$ channels are involved in this response ${ }^{16,85}$.

\section{Renal vascular $\mathrm{K}^{+}$channels in disease.}

\section{Hypertension}

$\mathrm{K}^{+}$channel function is altered in hypertension ${ }^{178}$. However, the manner of alteration may differ between channels. While $\mathrm{K}_{\mathrm{ATP}}$ and $\mathrm{K}_{\mathrm{ir}}$ channel function is supposed to be reduced in hypertension, $\mathrm{BK}_{\mathrm{Ca}}$ channel function is up-regulated ${ }^{16,178,179} . \mathrm{IK}_{\mathrm{Ca}}$ channel expression is also up-regulated during hypertension ${ }^{180}$. On the other hand, other authors reported a reduced expression of both $\mathrm{SK}_{\mathrm{Ca}}$ and $\mathrm{IK}_{\mathrm{Ca}}$ channels during Ang II-induced hypertension ${ }^{181}$. Likewise our laboratory has found that mRNA of $\mathrm{SK}_{\mathrm{Ca}}$ and $\mathrm{IK}_{\mathrm{Ca}}$ channels were significantly downregulated in obese fructose/fat fed rats with elevated blood pressure ${ }^{182}$. Regarding the renal vascular system, information is scarce. Comparing VSMC from renal interlobar arteries from WKY, SD, SHR and DOCA rats Martens and Gelband found an upregulation in $\mathrm{K}_{\mathrm{V}}$ channels activity and a down-regulation in $\mathrm{K}_{\mathrm{Ca}}$ channel activity ${ }^{183}$. It has also been reported that $\mathrm{K}_{\mathrm{ATP}}$ channel function is down-regulated in hypertension ${ }^{139,184}$. Activation of $\mathrm{BK}_{\mathrm{Ca}}$ in renal arteries from SHR was reduced compared to WKY possibly caused by a decrease in NO production ${ }^{185}$. Furthermore, expression of $\mathrm{K}_{\mathrm{V}} 7.4$ in renal arteries from SHR is significantly

This article is protected by copyright. All rights reserved. 
reduced ${ }^{112}$. However, there is an urgent need for studies dealing with altered renal vascular $\mathrm{K}^{+}$channels function in different forms of hypertension.

\section{Diabetes}

In diabetes mellitus (DM), elevated $\mathrm{K}_{\mathrm{ATP}}$ and $\mathrm{K}_{\mathrm{ir}}$ channel function may contribute to preglomerular vasodilation and hyperfiltration ${ }^{52,134,186}$. Kir1.1 and/or Kir3.x channels contribute to the afferent arteriolar dilation seen in $\mathrm{DM}^{52}$. The same study showed that the effect of TEA on afferent arteriolar diameter was similar in control rats and DM rats indicating that $\mathrm{BK}_{\mathrm{Ca}}$ channel function is not altered ${ }^{52}$. Also, glibenclamide constricted afferent arterioles from rats with DM while the effect was absent in normal rats ${ }^{134}$. Thus, increased $\mathrm{K}_{\mathrm{ATP}}$ channel function may contribute to the early DM hyperfiltration ${ }^{186}$. In addition, oxidative stress may contribute to the exaggerated vasodilating actions of Kir1.1, Kir2.1, and $\mathrm{K}_{\mathrm{ATP}}$ channels on afferent arteriolar tone during DM ${ }^{187}$. On the other hand, using clearance methods, Vallon et al. were unable to find any renal vascular effect of the $\mathrm{K}_{\mathrm{ATP}}$ channel blocker U37883A in rats with $\mathrm{DM}^{188}$. It is clear that there is a need for more research to fully elucidate a possible role for renal vascular $\mathrm{K}^{+}$channels in early diabetic hyperfiltration.

\section{Sepsis}

Activation of vascular $\mathrm{BK}_{\mathrm{Ca}}$ or $\mathrm{K}_{\mathrm{ATP}}$ channels may be involved in the hypotension associated with sepsis ${ }^{189-192}$. However, treatment with blockers or lack of these channels has not shown any beneficial effects ${ }^{193-195}$. Levosimendan, a $\mathrm{K}_{\mathrm{ATP}}$ channel activator, exhibited protection against lipopolysaccharide -induced acute renal failure ${ }^{189}$. This is in line with a study demonstrating that despite the fact that glibenclamide or iberiotoxin increased blood pressure and vascular reactivity to vasoconstrictors in septic animals, the treatment led to a substantial reduction in RBF especially after treatment with drugs, such as norepinephrine and phenylephrine putting renal perfusion at risk ${ }^{190}$.

\section{Concluding remarks}

It is clear that renal vascular $\mathrm{K}^{+}$-channels play a significant role in the regulation of renal vascular tone. In the literature, there is a considerable volume of information available regarding the role of the individual classes of renal vascular $\mathrm{K}^{+}$-channel in a variety of in vitro settings. However, studies characterizing $\mathrm{K}^{+}$currents in renal resistance vessels are 
sparse as are studies investigating these channels in in vivo settings. Information regarding the role of these channels in different disease conditions is especially scarce. An increased knowledge about renal vascular $\mathrm{K}^{+}$-channel function in physiology and during pathophysiological conditions such as hypertension, DM and sepsis may increase the potential for renoprotection in these conditions.

\section{Acknowledgements}

We would like to thank the "Stiftelsen Nordisk Fysiologi, SNF" and the German Research Foundation (Deutsche Forschungsgemeinschaft, DFG) for their generous support for the AP Symposium on "RENOPROTECTION". The authors were supported by grants from the Danish Medical Research Council, the Danish Heart Foundation, the Novo-Nordisk Foundation, the Lundbeck Foundation, the Koenig-Petersen Foundation and the A.P. Møller Foundation.

\section{Conflict of Interest}

None

\section{Table legends}

Table 1. The four super families of $\mathrm{K}^{+}$channels. Shown are the International Union of Basic and Clinical Pharmacology (IUPHAR) nomenclature for relevant members expressed in renal vascular tissue, the gene names and some of the common aliases.

Table 1: $\mathrm{K}^{+}$channels

\begin{tabular}{|c|c|c|c|c|}
\hline Family & Subtype & $\begin{array}{l}\text { Renal } \\
\text { vascular } \\
\text { members }\end{array}$ & Gene name & Alias \\
\hline \multirow[t]{3}{*}{$\mathrm{Ca}^{2+}$ activated (KCa) } & KCa1 & $\mathrm{K}_{\mathrm{Ca}} 1.1$ & KCNMA1 & $\mathrm{BK}_{\mathrm{Ca}}$ or Slo \\
\hline & $\mathrm{KCa} 2$ & $\mathrm{~K}_{\mathrm{Ca}} 2.1-2.3$ & KCNN1-3 & $\mathrm{SK}_{\mathrm{Ca}}$ or SK1-3 \\
\hline & $\mathrm{KCa} 3$ & $\mathrm{~K}_{\mathrm{Ca}} 3.1$ & KCNN4 & $\mathrm{IK}_{\mathrm{Ca}}$ \\
\hline \multirow[t]{3}{*}{ Inwardly rectifying $\left(\mathrm{K}_{\mathrm{ir}}\right)$} & $\mathrm{K}_{\mathrm{ir}} 1-6$ & $\mathrm{~K}_{\mathrm{ir}} 1.1$ & KCNJ1 & ROMK \\
\hline & & $\mathrm{K}_{\mathrm{ir}} 2.1-2.2$ & KCNJ2/12 & $\mathrm{K}_{\mathrm{ir}}$ \\
\hline & & $\mathrm{K}_{\mathrm{ir}} 6.1-6.2$ & $\mathrm{KCNJ8/11}$ & $\mathrm{K}_{\mathrm{ATP}}$ \\
\hline \multirow[t]{2}{*}{ Voltage gated $\left(\mathrm{K}_{\mathrm{V}}\right)$} & $\mathrm{K}_{\mathrm{V}} 1-12$ & $\mathrm{~K}_{\mathrm{V}} 1.1-1.8$ & KCNA1-7; 10 & $\mathrm{~K}_{\mathrm{V}}$ Shaker-related \\
\hline & & $\mathrm{K}_{\mathrm{V}} 7.1-7.5$ & KCNQ1-5 & KCNQ \\
\hline \multirow[t]{2}{*}{ Two-P } & $\mathrm{K} 2 \mathrm{P}$ & $\mathrm{K}_{2 \mathrm{P}} 2.1$ & KCNK2 & TREK-1 \\
\hline & & $\mathrm{K}_{2 \mathrm{P}} 3.1$ & KCNK3 & TASK-1 \\
\hline
\end{tabular}

This article is protected by copyright. All rights reserved. 
KCa nomenclature: ${ }^{196}$

$\mathrm{K}_{\text {ir }}$ nomenclature: ${ }^{197}$

$\mathrm{K}_{\mathrm{V}}$ channel nomenclature: ${ }^{198}$

K2P nomenclature: ${ }^{199}$

\section{Figure legends}

Figure 1. Pathways leading to vasoconstriction via deactivation of $\mathrm{K}^{+}$channels in vascular smooth muscle cells (shown with red arrows). The following depolarization and increase in $\left[\mathrm{Ca}^{2+}\right]_{\mathrm{i}}$ can activate $\mathrm{K}^{+}$channels to buffer the vasoconstriction (shown with green arrows). See text for details. Blue arrow $=$ effect; Red arrow $=$ deactivation; Green arrow $=$ activation. VOCC: voltage activated calcium channel, $\mathrm{V}_{\mathrm{m}}$ : membrane potential, $\mathrm{SR}$ : sarcoplasmatic reticulum, PKC: protein kinase $\mathrm{C}_{\text {, }} \mathrm{IP}_{3}$ : inositol trisphosphate, 20-HETE: 20-

Hydroxyeicosatetraenoic Acid

Figure 2. Pathways leading to vasodilation via activation of $\mathrm{K}^{+}$channels in endothelial cells or vascular smooth muscle. See text for details. Blue arrow = effect; Red arrow = inhibition; Green arrow $=$ activation .

ER: endoplasmatic reticulum, Cyt P450: cytochrome P450, NOS: nitric oxide synthase, $\mathrm{V}_{\mathrm{m}}$ : membrane potential, EET: Epoxyeicosatrienoic acids, MEGJ: myoendothelial gap junctions, $\mathrm{K}^{+}{ }_{\mathrm{EC}}: \mathrm{K}^{+}$released from the endothelial cell, cGMP: cyclic GMP, PKG: protein kinase G, VOCC: voltage activated calcium channel, PKA: protein kinase A

Figure 3. Current-voltage relationship for $\mathrm{K}_{\mathrm{ir}}$ channels at three different extracellular $\mathrm{K}^{+}$ concentrations. The curves are calculated using the equations for the Kir channel in Edwards et $\mathrm{al}^{74}$. $\mathrm{E}_{\mathrm{K}}$ used is calculated from the Nernst equation using $\left[\mathrm{K}^{+}\right]_{\text {out }}=5 \mathrm{mM}, 12 \mathrm{mM}$ or 20 $\mathrm{mM}$ and $\left[\mathrm{K}^{+}\right]_{\text {in }}=130 \mathrm{mM} . \mathrm{V}_{\mathrm{m}}$ covers the range of measured values $(-55 \mathrm{mV}--40 \mathrm{mV})$ in afferent arteriolar VSMC ${ }^{17,121}$.

This article is protected by copyright. All rights reserved. 


\section{Reference List}

1. Vavrinec, P, Henning, RH, Goris, M, Vavrincova-Yaghi, D, Buikema, H, van Dokkum, RP: Vascular smooth muscle function of renal glomerular and interlobar arteries predicts renal damage in rats. Am J Physiol Renal Physiol, 303: F1187-F1195, 2012.

2. Xue, H, Zhang, YL, Liu, GS, Wang, H: A new ATP-sensitive potassium channel opener protects the kidney from hypertensive damage in spontaneously hypertensive rats. $J$ Pharmacol Exp Ther, 315: 501-509, 2005.

3. Salomonsson, M, Arendshorst, WJ: Calcium recruitment in renal vasculature: NE effects on blood flow and cytosolic calcium concentration. Am J Physiol, 276: F700-F710, 1999.

4. Salomonsson, M, Sorensen, CM, Arendshorst, WJ, Steendahl, J, Holstein-Rathlou, NH: Calcium handling in afferent arterioles. Acta Physiol Scand, 181: 421-429, 2004.

5. Carmines, PK, Fowler, BC, Bell, PD: Segmentally distinct effects of depolarization on intracellular Ca2+- in renal arterioles. Am J Physiol: F677-F685, 1993.

6. Navar, LG, Champion, WJ, Thomas, CE: Effects of calcium channel blockade on renal vascular resistance responses to changes in perfusion pressure and angiotensinconverting enzyme inhibition in dogs. Circ Res, 58: 874-881, 1986.

7. Hayashi, K, Wakino, S, Sugano, N, Ozawa, Y, Homma, K, Saruta, T: Ca2+ channel subtypes and pharmacology in the kidney. Circ Res, 100: 342-353, 2007.

8. Hansen, PB, Jensen, BL, Andreasen, D, Skott, O: Differential expression of T- and L-type voltage-dependent calcium channels in renal resistance vessels. Circ Res, 89: 630638, 2001.

9. Feng, MG, Li, M, Navar, LG: T-type calcium channels in the regulation of afferent and efferent arterioles in rats. Am J Physiol Renal Physiol, 286: F331-F337, 2004.

10. Sorensen, CM, Giese, I, Braunstein, TH, Holstein-Rathlou, NH, Salomonsson, M: Closure of multiple types of $\mathrm{K}(+)$ channels is necessary to induce changes in renal vascular resistance in vivo in rats. Pflugers Arch, 462: 655-667, 2011.

11. Smirnov, SV, Loutzenhiser, K, Loutzenhiser, R: Voltage-activated $\mathrm{Ca}(2+)$ channels in rat renal afferent and efferent myocytes: no evidence for the T-type $\mathrm{Ca}(2+)$ current. Cardiovasc Res, 97: 293-301, 2013.

12. Frandsen, RH, Salomonsson, M, Hansen, PB, Jensen, LJ, Braunstein, TH, HolsteinRathlou, NH, Sorensen, CM: No apparent role for T-type $\mathrm{Ca}(2)(+)$ channels in renal autoregulation. Pflugers Arch, 468: 541-550, 2016.

13. Jensen, LJ, Nielsen, MS, Salomonsson, M, Sorensen, CM: T-type Ca2+ channels and autoregulation of local blood flow. Channels (Austin): 1-13, 2017.

14. Kohler, R, Ruth, P: Endothelial dysfunction and blood pressure alterations in K+-channel transgenic mice. Pflugers Arch, 459: 969-976, 2010.

15. Rasmussen, KM, Braunstein, TH, Salomonsson, M, Brasen, JC, Sorensen, CM: Contribution of $\mathrm{K}$ channels to endothelium-derived hypolarization-induced renal vasodilation in rats in vivo and in vitro. Pflugers Arch, 2016.

16. Ko, EA, Han, J, Jung, ID, Park, WS: Physiological roles of K+ channels in vascular smooth muscle cells. J Smooth Muscle Res, 44: 65-81, 2008.

17. Buhrle, CP, Nobiling, R, Mannek, E, Schneider, D, Hackenthal, E, Taugner, R: The afferent glomerular arteriole: immunocytochemical and electrophysiological investigations. J Cardiovasc Pharmacol, 6 Suppl 2: S383-S393, 1984.

18. Chilton, L, Loutzenhiser, R: Functional Evidence for an Inward Rectifier Potassium Current in Rat Renal Afferent Arterioles. Circ Res, 88: 152-158, 2001.

This article is protected by copyright. All rights reserved. 
19. Nelson, MT, Patlak, JB, Worley, JF, Standen, NB: Calcium channels, potassium channels, and voltage dependence of arterial smooth muscle tone. Am J Physiol, 259: C3-18, 1990.

20. Jensen, LJ, Salomonsson, M, Jensen, BL, Holstein-Rathlou, NH: Depolarization-induced calcium influx in rat mesenteric small arterioles is mediated exclusively via mibefradil-sensitive calcium channels. Br J Pharmacol, 142: 709-718, 2004.

21. Jackson, WF: Hypoxia does not activate ATP-sensitive $\mathrm{K}+$ channels in arteriolar muscle cells. Microcirculation, 7: 137-145, 2000.

22. Sorensen, CM, Braunstein, TH, Holstein-Rathlou, NH, Salomonsson, M: Role of vascular potassium channels in the regulation of renal hemodynamics. Am J Physiol Renal Physiol, 302: F505-F518, 2012.

23. Yokoshiki, H, Sunagawa, M, Seki, T, Sperelakis, N: ATP-sensitive K+ channels in pancreatic, cardiac, and vascular smooth muscle cells. Am J Physiol, 274: C25-C37, 1998.

24. Alexander, SP, Mathie, A, Peters, JA: Guide to Receptors and Channels (GRAC), 5th edition. Br J Pharmacol, 164 Suppl 1: S1-324, 2011.

25. Kestler, HA, Janko, S, Haussler, U, Muche, R, Hombach, V, Hoher, M, Wiecha, J: A remark on the high-conductance calcium-activated potassium channel in human endothelial cells. Res Exp Med (Berl), 198: 133-143, 1998.

26. Wiecha, J, Schlager, B, Voisard, R, Hannekum, A, Mattfeldt, T, Hombach, V: Ca(2+)activated $\mathrm{K}+$ channels in human smooth muscle cells of coronary atherosclerotic plaques and coronary media segments. Basic Res Cardiol, 92: 233-239, 1997.

27. Hill, MA, Yang, Y, Ella, SR, Davis, MJ, Braun, AP: Large conductance, Ca2+-activated $\mathrm{K}+$ channels (BKCa) and arteriolar myogenic signaling. FEBS Lett, 584: 2033-2042, 2010.

28. Neild, TO, Keef, K: Measurements of the membrane potential of arterial smooth muscle in anesthetized animals and its relationship to changes in artery diameter. Microvasc Res, 30: 19-28, 1985.

29. Brayden, JE, Nelson, MT: Regulation of arterial tone by activation of calcium-dependent potassium channels. Science, 256: 532-535, 1992.

30. Sah, $\mathrm{P}: \mathrm{Ca}(2+)$-activated $\mathrm{K}+$ currents in neurones: types, physiological roles and modulation. Trends Neurosci, 19: 150-154, 1996.

31. Barman, SA, Zhu, S, White, RE: PKC activates BKCa channels in rat pulmonary arterial smooth muscle via cGMP-dependent protein kinase. Am J Physiol Lung Cell Mol Physiol, 286: L1275-L1281, 2004.

32. Minami, K, Fukuzawa, K, Nakaya, Y, Zeng, XR, Inoue, I: Mechanism of activation of the $\mathrm{Ca}(2+)$-activated $\mathrm{K}+$ channel by cyclic AMP in cultured porcine coronary artery smooth muscle cells. Life Sci, 53: 1129-1135, 1993.

33. Zhou, XB, Arntz, C, Kamm, S, Motejlek, K, Sausbier, U, Wang, GX, Ruth, P, Korth, M: A molecular switch for specific stimulation of the BKCa channel by cGMP and cAMP kinase. J Biol Chem, 276: 43239-43245, 2001.

34. Standen, NB, Quayle, JM: K+ channel modulation in arterial smooth muscle. Acta Physiol Scand, 164: 549-557, 1998.

35. Lange, A, Gebremedhin, D, Narayanan, J, Harder, D: 20-Hydroxyeicosatetraenoic acidinduced vasoconstriction and inhibition of potassium current in cerebral vascular smooth muscle is dependent on activation of protein kinase C. J Biol Chem, 272: 27345-27352, 1997.

36. Crozatier, B: Central role of PKCs in vascular smooth muscle cell ion channel regulation. J Mol Cell Cardiol, 41: 952-955, 2006.

This article is protected by copyright. All rights reserved. 
37. Archer, SL, Huang, JM, Hampl, V, Nelson, DP, Shultz, PJ, Weir, EK: Nitric oxide and cGMP cause vasorelaxation by activation of a charybdotoxin-sensitive $\mathrm{K}$ channel by cGMP-dependent protein kinase. Proc Natl Acad Sci U S A, 91: 7583-7587, 1994.

38. Olesen, SP, Munch, E, Moldt, P, Drejer, J: Selective activation of $\mathrm{Ca}(2+)$-dependent K+ channels by novel benzimidazolone. Eur J Pharmacol, 251: 53-59, 1994.

39. Nelson, MT, Quayle, JM: Physiological roles and properties of potassium channels in arterial smooth muscle. Am J Physiol, 268: C799-C822, 1995.

40. Jackson, WF, Blair, KL: Characterization and function of $\mathrm{Ca}(2+)$-activated $\mathrm{K}+$ channels in arteriolar muscle cells. Am J Physiol, 274: H27-H34, 1998.

41. Berkefeld, H, Sailer, CA, Bildl, W, Rohde, V, Thumfart, JO, Eble, S, Klugbauer, N, Reisinger, E, Bischofberger, J, Oliver, D, Knaus, HG, Schulte, U, Fakler, B: BKCa$\mathrm{Cav}$ channel complexes mediate rapid and localized $\mathrm{Ca} 2+$-activated $\mathrm{K}+$ signaling. Science, 314: 615-620, 2006.

42. Guia, A, Wan, X, Courtemanche, M, Leblanc, N: Local Ca2+ entry through L-type Ca2+ channels activates $\mathrm{Ca} 2+-$ dependent $\mathrm{K}+$ channels in rabbit coronary myocytes. Circ Res, 84: 1032-1042, 1999.

43. Wellman, GC, Nathan, DJ, Saundry, CM, Perez, G, Bonev, AD, Penar, PL, Tranmer, BI, Nelson, MT: Ca2+ sparks and their function in human cerebral arteries. Stroke, 33: 802-808, 2002.

44. Magnusson, L, Sorensen, CM, Braunstein, TH, Holstein-Rathlou, NH, Salomonsson, M: Renovascular $\mathrm{BK}(\mathrm{Ca})$ channels are not activated in vivo under resting conditions and during agonist stimulation. Am J Physiol Regul Integr Comp Physiol, 292: R345R353, 2007.

45. Friis, UG, Jorgensen, F, Andreasen, D, Jensen, BL, Skott, O: Molecular and functional identification of cyclic AMP-sensitive BKCa potassium channels (ZERO variant) and L-type voltage-dependent calcium channels in single rat juxtaglomerular cells. Circ Res, 93: 213-220, 2003.

46. Stockand, JD, Sansom, SC: Large $\mathrm{Ca}(2+)$-activated $\mathrm{K}+$ channels responsive to angiotensin II in cultured human mesangial cells. Am J Physiol, 267: C1080-C1086, 1994.

47. Stockand, JD, Sansom, SC: Role of large $\mathrm{Ca}(2+)$-activated $\mathrm{K}+$ channels in regulation of mesangial contraction by nitroprusside and ANP. Am J Physiol, 270: C1773-C1779, 1996.

48. Kurtz, A, Hamann, M, Gotz, K: Role of potassium channels in the control of renin secretion from isolated perfused rat kidneys. Pflugers Arch, 440: 889-895, 2000.

49. Rapacon, M, Mieyal, P, McGiff, JC, Fulton, D, Quilley, J: Contribution of calciumactivated potassium channels to the vasodilator effect of bradykinin in the isolated, perfused kidney of the rat. Br J Pharmacol, 118: 1504-1508, 1996.

50. Su, J, Yu, H, Lenka, N, Hescheler, J, Ullrich, S: The expression and regulation of depolarization-activated $\mathrm{K}+$ channels in the insulin-secreting cell line INS-1. Pflugers Arch, 442: 49-56, 2001.

51. Orito, K, Yanagisawa, T, Taira, N: A possibility that the ATP-sensitive potassium channel in coronary artery has a high-affinity internal binding site for tetraalkylammonium. Jpn J Pharmacol, 64: 297-301, 1994.

52. Troncoso Brindeiro, CM, Fallet, RW, Lane, PH, Carmines, PK: Potassium channel contributions to afferent arteriolar tone in normal and diabetic rat kidney. Am J Physiol Renal Physiol, 295: F171-F178, 2008.

53. Imig, JD, Zou, AP, Stec, DE, Harder, DR, Falck, JR, Roman, RJ: Formation and actions of 20-hydroxyeicosatetraenoic acid in rat renal arterioles. Am J Physiol, 270: R217R227, 1996.

This article is protected by copyright. All rights reserved. 
54. Fallet, RW, Bast, JP, Fujiwara, K, Ishii, N, Sansom, SC, Carmines, PK: Influence of $\mathrm{Ca}(2)$-activated $\mathrm{K}()$ channels on rat renal arteriolar responses to depolarizing agonists. Am J Physiol Renal Physiol: F583-F591, 2001.

55. Belevych, AE, Beck, R, Tammaro, P, Poston, L, Smirnov, SV: Developmental changes in the functional characteristics and expression of voltage-gated $\mathrm{K}+$ channel currents in rat aortic myocytes. Cardiovasc Res, 54: 152-161, 2002.

56. Heaps, CL, Jeffery, EC, Laine, GA, Price, EM, Bowles, DK: Effects of exercise training and hypercholesterolemia on adenosine activation of voltage-dependent $\mathrm{K}+$ channels in coronary arterioles. J Appl Physiol (1985), 105: 1761-1771, 2008.

57. Holland, M, Langton, PD, Standen, NB, Boyle, JP: Effects of the BKCa channel activator, NS1619, on rat cerebral artery smooth muscle. Br J Pharmacol, 117: 119129, 1996.

58. Edwards, G, Niederste-Hollenberg, A, Schneider, J, Noack, T, Weston, AH: Ion channel modulation by NS 1619, the putative BKCa channel opener, in vascular smooth muscle. Br J Pharmacol, 113: 1538-1547, 1994.

59. Loutzenhiser, RD, Parker, MJ: Hypoxia inhibits myogenic reactivity of renal afferent arterioles by activating ATP-sensitive K+ channels. Circ Res, 74: 861-869, 1994.

60. Tian, L, Coghill, LS, McClafferty, H, MacDonald, SH, Antoni, FA, Ruth, P, Knaus, HG, Shipston, MJ: Distinct stoichiometry of BKCa channel tetramer phosphorylation specifies channel activation and inhibition by cAMP-dependent protein kinase. Proc Natl Acad Sci U S A, 101: 11897-11902, 2004.

61. Pluznick, JL, Wei, P, Carmines, PK, Sansom, SC: Renal fluid and electrolyte handling in BKCa-beta1-/- mice. Am J Physiol Renal Physiol, 284: F1274-F1279, 2003.

62. Lu, R, Alioua, A, Kumar, Y, Eghbali, M, Stefani, E, Toro, L: MaxiK channel partners: physiological impact. J Physiol, 570: 65-72, 2006.

63. Fellner, SK, Arendshorst, WJ: Complex interactions of NO/cGMP/PKG systems on Ca2+ signaling in afferent arteriolar vascular smooth muscle. Am J Physiol Heart Circ Physiol, 298: H144-H151, 2010.

64. Wang, X, Loutzenhiser, R: Determinants of renal microvascular response to ACh: afferent and efferent arteriolar actions of EDHF. Am J Physiol Renal Physiol, 282: F124-F132, 2002.

65. Badzynska, B, Sadowski, J: Renal hemodynamic responses to intrarenal infusion of acetylcholine: comparison with effects of PGE2 and NO donor. Kidney Int, 69: 17741779, 2006.

66. Ozawa, Y, Hayashi, K, Nagahama, T, Fujiwara, K, Kanda, T, Homma, K, Saruta, T: Distinct role of nitric oxide and endothelium-derived hyperpolarizing factor in renal microcirculation. Studies in the isolated perfused hydronephrotic kidney. Nephron, 92: 905-913, 2002.

67. Imig, JD, Dimitropoulou, C, Reddy, DS, White, RE, Falck, JR: Afferent arteriolar dilation to 11, 12-EET analogs involves PP2A activity and Ca2+-activated $\mathrm{K}+$ Channels. Microcirculation, 15: 137-150, 2008.

68. Wang, X, Trottier, G, Loutzenhiser, R: Determinants of renal afferent arteriolar actions of bradykinin: evidence that multiple pathways mediate responses attributed to EDHF. Am J Physiol Renal Physiol, 285: F540-F549, 2003.

69. Gebremedhin, D, Kaldunski, M, Jacobs, ER, Harder, DR, Roman, RJ: Coexistence of two types of $\mathrm{Ca}(2+)$-activated $\mathrm{K}+$ channels in rat renal arterioles. Am J Physiol, 270: F69F81, 1996.

70. Zaritsky, JJ, Eckman, DM, Wellman, GC, Nelson, MT, Schwarz, TL: Targeted disruption of Kir2.1 and Kir2.2 genes reveals the essential role of the inwardly rectifying $\mathrm{K}(+)$ current in $\mathrm{K}(+)$-mediated vasodilation. Circ Res, 87: 160-166, 2000.

This article is protected by copyright. All rights reserved. 
71. Bradley, KK, Jaggar, JH, Bonev, AD, Heppner, TJ, Flynn, ER, Nelson, MT, Horowitz, B: Kir2.1 encodes the inward rectifier potassium channel in rat arterial smooth muscle cells. J Physiol, 515 ( Pt 3): 639-651, 1999.

72. Edwards, FR, Hirst, GD: Inward rectification in submucosal arterioles of guinea-pig ileum. J Physiol, 404: 437-454, 1988.

73. Quayle, JM, Dart, C, Standen, NB: The properties and distribution of inward rectifier potassium currents in pig coronary arterial smooth muscle. J Physiol, 494 ( Pt 3): 715726, 1996.

74. Edwards, A, Layton, AT: Calcium dynamics underlying the myogenic response of the renal afferent arteriole. Am J Physiol Renal Physiol, 306: F34-48, 2014.

75. Liu, TA, Chang, HK, Shieh, RC: Extracellular K+ elevates outward currents through Kir2.1 channels by increasing single-channel conductance. Biochim Biophys Acta, 1808: 1772-1778, 2011.

76. Lopatin, AN, Nichols, CG: $[\mathrm{K}+]$ dependence of polyamine-induced rectification in inward rectifier potassium channels (IRK1, Kir2.1). J Gen Physiol, 108: 105-113, 1996.

77. Guo, D, Ramu, Y, Klem, AM, Lu, Z: Mechanism of rectification in inward-rectifier K+ channels. J Gen Physiol, 121: 261-275, 2003.

78. Smith, PD, Brett, SE, Luykenaar, KD, Sandow, SL, Marrelli, SP, Vigmond, EJ, Welsh, DG: KIR channels function as electrical amplifiers in rat vascular smooth muscle. $J$ Physiol, 586: 1147-1160, 2008.

79. Jantzi, MC, Brett, SE, Jackson, WF, Corteling, R, Vigmond, EJ, Welsh, DG: Inward rectifying potassium channels facilitate cell-to-cell communication in hamster retractor muscle feed arteries. Am J Physiol Heart Circ Physiol, 291: H1319-H1328, 2006.

80. Rivers, RJ, Hein, TW, Zhang, C, Kuo, L: Activation of barium-sensitive inward rectifier potassium channels mediates remote dilation of coronary arterioles. Circulation, 104: 1749-1753, 2001.

81. Goto, K, Rummery, NM, Grayson, TH, Hill, CE: Attenuation of conducted vasodilatation in rat mesenteric arteries during hypertension: role of inwardly rectifying potassium channels. J Physiol, 561: 215-231, 2004.

82. Quayle, JM, McCarron, JG, Brayden, JE, Nelson, MT: Inward rectifier K+ currents in smooth muscle cells from rat resistance-sized cerebral arteries. Am J Physiol, 265: C1363-C1370, 1993.

83. Knot, HJ, Zimmermann, PA, Nelson, MT: Extracellular K(+)-induced hyperpolarizations and dilatations of rat coronary and cerebral arteries involve inward rectifier $\mathrm{K}(+)$ channels. J Physiol, 492 ( Pt 2): 419-430, 1996.

84. Edwards, FR, Hirst, GD, Silverberg, GD: Inward rectification in rat cerebral arterioles; involvement of potassium ions in autoregulation. J Physiol, 404: 455-466, 1988.

85. Jackson, WF: Potassium channels in the peripheral microcirculation. Microcirculation, 12: 113-127, 2005.

86. Edwards, G, Dora, KA, Gardener, MJ, Garland, CJ, Weston, AH: K+ is an endotheliumderived hyperpolarizing factor in rat arteries. Nature, 396: 269-272, 1998.

87. Webb, RC, Bohr, DF: Potassium-induced relaxation as an indicator of Na+-K+ ATPase activity in vascular smooth muscle. Blood Vessels, 15: 198-207, 1978.

88. Chilton, L, Loutzenhiser, K, Morales, E, Breaks, J, Kargacin, GJ, Loutzenhiser, R: Inward rectifier $\mathrm{K}+$ currents and Kir2.1 expression in renal afferent and efferent arterioles. J Am Soc Nephrol, 19: 69-76, 2008.

This article is protected by copyright. All rights reserved. 
89. Magnusson, L, Sorensen, CM, Braunstein, TH, Holstein-Rathlou, NH, Salomonsson, M: Mechanisms of $\mathrm{K}(+)$ induced renal vasodilation in normo- and hypertensive rats in vivo. Acta Physiol (Oxf), 2011.

90. Cao, C, Lee-Kwon, W, Payne, K, Edwards, A, Pallone, TL: Descending vasa recta endothelia express inward rectifier potassium channels. Am J Physiol Renal Physiol, 293: F1248-F1255, 2007.

91. Cao, C, Goo, JH, Lee-Kwon, W, Pallone, TL: Vasa recta pericytes express a strong inward rectifier K+ conductance. Am J Physiol Regul Integr Comp Physiol, 290: R1601-R1607, 2006.

92. Chilton, L, Smirnov, SV, Loutzenhiser, K, Wang, X, Loutzenhiser, R: Segment-specific differences in the inward rectifier $\mathrm{K}(+)$ current along the renal interlobular artery. Cardiovasc Res, 92: 169-177, 2011.

93. Leichtle, A, Rauch, U, Albinus, M, Benohr, P, Kalbacher, H, Mack, AF, Veh, RW, Quast, U, Russ, U: Electrophysiological and molecular characterization of the inward rectifier in juxtaglomerular cells from rat kidney. J Physiol, 560: 365-376, 2004.

94. Kurtz, A, Penner, R: Angiotensin II induces oscillations of intracellular calcium and blocks anomalous inward rectifying potassium current in mouse renal juxtaglomerular cells. Proc Natl Acad Sci U S A, 86: 3423-3427, 1989.

95. Hollenberg, NK, Williams, G, Burger, B, Hooshmand, I: The influence of potassium on the renal vasculature and the adrenal gland, and their responsiveness to angiotensin II in normal man. Clin Sci Mol Med, 49: 527-534, 1975.

96. Young, DB, Lin, H, McCabe, RD: Potassium's cardiovascular protective mechanisms. Am J Physiol, 268: R825-R837, 1995.

97. Murphy, ME, Cohen, DB: Vasoactive effects of potassium in kidneys of hypertensive rats fed a high-potassium diet. J Hypertens, 17: 1481-1488, 1999.

98. SCOTT, J, EMANUEL, D, HADDY, F: Effect of potassium on renal vascular resistance and urine flow rate. Am J Physiol, 197: 305-308, 1959.

99. Bazzano, LA, He, J, Ogden, LG, Loria, C, Vupputuri, S, Myers, L, Whelton, PK: Dietary potassium intake and risk of stroke in US men and women: National Health and Nutrition Examination Survey I epidemiologic follow-up study. Stroke, 32: 14731480, 2001.

100. Prior, HM, Webster, N, Quinn, K, Beech, DJ, Yates, MS: K(+)-induced dilation of a small renal artery: no role for inward rectifier $\mathrm{K}+$ channels. Cardiovasc Res, 37: 780790, 1998.

101. Solc, CK, Aldrich, RW: Voltage-gated potassium channels in larval CNS neurons of Drosophila. J Neurosci, 8: 2556-2570, 1988.

102. Chung, S, Kaczmarek, LK: Modulation of the inactivation of voltage-dependent potassium channels by cAMP. J Neurosci, 15: 3927-3935, 1995.

103. Vazquez-Garcia, M, Reyes-Guerrero, G: Three types of single voltage-dependent potassium channels in the sarcolemma of frog skeletal muscle. J Membr Biol, 228: 51-62, 2009.

104. Zhou, ZH, Unlap, T, Li, L, Ma, HP: Incomplete inactivation of voltage-dependent K+ channels in human B lymphoma cells. J Membr Biol, 188: 97-105, 2002.

105. Korovkina, VP, England, SK: Molecular diversity of vascular potassium channel isoforms. Clin Exp Pharmacol Physiol, 29: 317-323, 2002.

106. Cheong, A, Dedman, AM, Xu, SZ, Beech, DJ: K(V)alpha1 channels in murine arterioles: differential cellular expression and regulation of diameter. Am J Physiol Heart Circ Physiol, 281: H1057-H1065, 2001.

107. Kerr, PM, Clement-Chomienne, O, Thorneloe, KS, Chen, TT, Ishii, K, Sontag, DP, Walsh, MP, Cole, WC: Heteromultimeric Kv1.2-Kv1.5 channels underlie 4-

This article is protected by copyright. All rights reserved. 
aminopyridine-sensitive delayed rectifier $\mathrm{K}(+)$ current of rabbit vascular myocytes. Circ Res, 89: 1038-1044, 2001.

108. Thorneloe, KS, Chen, TT, Kerr, PM, Grier, EF, Horowitz, B, Cole, WC, Walsh, MP: Molecular composition of 4-aminopyridine-sensitive voltage-gated $\mathrm{K}(+)$ channels of vascular smooth muscle. Circ Res, 89: 1030-1037, 2001.

109. Zhong, XZ, Harhun, MI, Olesen, SP, Ohya, S, Moffatt, JD, Cole, WC, Greenwood, IA: Participation of KCNQ (Kv7) potassium channels in myogenic control of cerebral arterial diameter. J Physiol, 588: 3277-3293, 2010.

110. Cox, RH: Molecular determinants of voltage-gated potassium currents in vascular smooth muscle. Cell Biochem Biophys, 42: 167-195, 2005.

111. Salomonsson, M, Brasen, JC, Braunstein, TH, Hagelqvist, P, Holstein-Rathlou, NH, Sorensen, CM: K(V)7.4 channels participate in the control of rodent renal vascular resting tone. Acta Physiol (Oxf), 214: 402-414, 2015.

112. Chadha, PS, Zunke, F, Zhu, HL, Davis, AJ, Jepps, TA, Olesen, SP, Cole, WC, Moffatt, JD, Greenwood, IA: Reduced KCNQ4-encoded voltage-dependent potassium channel activity underlies impaired beta-adrenoceptor-mediated relaxation of renal arteries in hypertension. Hypertension, 59: 877-884, 2012.

113. Glazebrook, PA, Ramirez, AN, Schild, JH, Shieh, CC, Doan, T, Wible, BA, Kunze, DL: Potassium channels Kv1.1, Kv1.2 and Kv1.6 influence excitability of rat visceral sensory neurons. J Physiol, 541: 467-482, 2002.

114. Betts, LC, Kozlowski, RZ: Electrophysiological effects of endothelin-1 and their relationship to contraction in rat renal arterial smooth muscle. Br J Pharmacol, 130: 787-796, 2000.

115. Ko, EA, Park, WS, Firth, AL, Kim, N, Yuan, JX, Han, J: Pathophysiology of voltagegated $\mathrm{K}+$ channels in vascular smooth muscle cells: modulation by protein kinases. Prog Biophys Mol Biol, 103: 95-101, 2010.

116. Cairrao, E, Santos-Silva, AJ, Verde, I: PKG is involved in testosterone-induced vasorelaxation of human umbilical artery. Eur J Pharmacol, 640: 94-101, 2010.

117. Aiello, EA, Clement-Chomienne, O, Sontag, DP, Walsh, MP, Cole, WC: Protein kinase $\mathrm{C}$ inhibits delayed rectifier $\mathrm{K}+$ current in rabbit vascular smooth muscle cells. Am J Physiol, 271: H109-H119, 1996.

118. Aiello, EA, Walsh, MP, Cole, WC: Phosphorylation by protein kinase A enhances delayed rectifier $\mathrm{K}+$ current in rabbit vascular smooth muscle cells. Am J Physiol, 268: H926-H934, 1995.

119. Aiello, EA, Malcolm, AT, Walsh, MP, Cole, WC: Beta-adrenoceptor activation and PKA regulate delayed rectifier $\mathrm{K}+$ channels of vascular smooth muscle cells. Am J Physiol, 275: H448-H459, 1998.

120. Berger, MG, Vandier, C, Bonnet, P, Jackson, WF, Rusch, NJ: Intracellular acidosis differentially regulates $\mathrm{KV}$ channels in coronary and pulmonary vascular muscle. Am J Physiol, 275: H1351-H1359, 1998.

121. Loutzenhiser, R, Chilton, L, Trottier, G: Membrane potential measurements in renal afferent and efferent arterioles: actions of angiotensin II. Am J Physiol, 273: F307F314, 1997.

122. Mackie, AR, Byron, KL: Cardiovascular KCNQ (Kv7) potassium channels: physiological regulators and new targets for therapeutic intervention. Mol Pharmacol, 74: 1171-1179, 2008.

123. Greenwood, IA, Ohya, S: New tricks for old dogs: KCNQ expression and role in smooth muscle. Br J Pharmacol, 156: 1196-1203, 2009.

This article is protected by copyright. All rights reserved. 
124. Fergus, DJ, Martens, JR, England, SK: Kv channel subunits that contribute to voltagegated K+ current in renal vascular smooth muscle. Pflugers Arch, 445: 697-704, 2003.

125. Gordienko, DV, Clausen, C, Goligorsky, MS: Ionic currents and endothelin signaling in smooth muscle cells from rat renal resistance arteries. Am J Physiol, 266: F325-F341, 1994.

126. Prior, HM, Yates, MS, Beech, DJ: Functions of large conductance Ca2+-activated (BKCa), delayed rectifier (KV) and background $\mathrm{K}+$ channels in the control of membrane potential in rabbit renal arcuate artery. J Physiol, 511 ( Pt 1): 159-169, 1998.

127. Zou, AP, Fleming, JT, Falck, JR, Jacobs, ER, Gebremedhin, D, Harder, DR, Roman, RJ: 20-HETE is an endogenous inhibitor of the large-conductance $\mathrm{Ca}(2+)$-activated $\mathrm{K}+$ channel in renal arterioles. Am J Physiol, 270: R228-R237, 1996.

128. Fretwell, LV, Woolard, J: Cardiovascular responses to retigabine in conscious rats-under normotensive and hypertensive conditions. Br J Pharmacol, 169: 1279-1289, 2013.

129. Lorenz, JN, Schnermann, J, Brosius, FC, Briggs, JP, Furspan, PB: Intracellular ATP can regulate afferent arteriolar tone via ATP-sensitive $\mathrm{K}+$ channels in the rabbit. J Clin Invest, 90: 733-740, 1992.

130. Ngo, AT, Jensen, LJ, Riemann, M, Holstein-Rathlou, NH, Torp-Pedersen, C: Oxygen sensing and conducted vasomotor responses in mouse cremaster arterioles in situ. Pflugers Arch, 460: 41-53, 2010.

131. Nelson, MT, Brayden, JE: Regulation of arterial tone by calcium-dependent K+ channels and ATP-sensitive K+ channels. Cardiovasc Drugs Ther, 7 Suppl 3: 605610, 1993.

132. Li, L, Wu, J, Jiang, C: Differential expression of Kir6.1 and SUR2B mRNAs in the vasculature of various tissues in rats. J Membr Biol, 196: 61-69, 2003.

133. Jensen, BL, Gambaryan, S, Scholz, H, Kurtz, A: KATP channels are not essential for pressure-dependent control of renin secretion. Pflugers Arch, 435: 670-677, 1998.

134. Ikenaga, H, Bast, JP, Fallet, RW, Carmines, PK: Exaggerated impact of ATP-sensitive $\mathrm{K}(+)$ channels on afferent arteriolar diameter in diabetes mellitus. J Am Soc Nephrol, 11: 1199-1207, 2000.

135. De Vriese, AS, Blom, HJ, Heil, SG, Mortier, S, Kluijtmans, LA, Van, d, V, Lameire, $\mathrm{NH}$ : Endothelium-derived hyperpolarizing factor-mediated renal vasodilatory response is impaired during acute and chronic hyperhomocysteinemia. Circulation, 109: 2331-2336, 2004.

136. Miura, K, Ebara, T, Okumura, M, Matsuura, T, Kim, S, Yukimura, T, Iwao, H: Attenuation of adrenomedullin-induced renal vasodilatation by NG-nitro L-arginine but not glibenclamide. Br J Pharmacol, 115: 917-924, 1995.

137. Yamashita, T, Masuda, Y, Kawamura, N, Fujikura, N, Tanaka, S: Comparative study of vasodilator effects of the potassium channel openers NIP-121 and levcromakalim in dogs and rats. Jpn J Pharmacol, 68: 145-152, 1995.

138. Uchida, W, Masuda, N, Taguchi, T, Shibasaki, K, Shirai, Y, Asano, M, Matsumoto, Y, Tsuzuki, R, Fujikura, T, Takenaka, T: Pharmacologic profiles of YM934, a novel potassium channel opener. J Cardiovasc Pharmacol, 23: 180-187, 1994.

139. Kawata, T, Mimuro, T, Onuki, T, Tsuchiya, K, Nihei, H, Koike, T: The K(ATP) channel opener nicorandil: effect on renal hemodynamics in spontaneously hypertensive and Wistar Kyoto rats. Kidney Int Suppl, 67:S231-3: S231-S233, 1998.

This article is protected by copyright. All rights reserved. 
140. Cao, C, Lee-Kwon, W, Silldorff, EP, Pallone, TL: KATP channel conductance of descending vasa recta pericytes. Am J Physiol Renal Physiol, 289: F1235-F1245, 2005.

141. Reslerova, M, Loutzenhiser, R: Renal microvascular actions of calcitonin gene-related peptide. Am J Physiol, 274: F1078-F1085, 1998.

142. Tang, L, Parker, M, Fei, Q, Loutzenhiser, R: Afferent arteriolar adenosine A2a receptors are coupled to KATP in in vitro perfused hydronephrotic rat kidney. Am J Physiol, 277: F926-F933, 1999.

143. Nilius, B, Viana, F, Droogmans, G: Ion channels in vascular endothelium. Annu Rev Physiol, 59: 145-170, 1997.

144. Muraki, K, Imaizumi, Y, Ohya, S, Sato, K, Takii, T, Onozaki, K, Watanabe, M: Apamin-sensitive $\mathrm{Ca} 2+-$ dependent $\mathrm{K}+$ current and hyperpolarization in human endothelial cells. Biochem Biophys Res Commun, 236: 340-343, 1997.

145. Brakemeier, S, Eichler, I, Knorr, A, Fassheber, T, Kohler, R, Hoyer, J: Modulation of $\mathrm{Ca} 2+$-activated $\mathrm{K}+$ channel in renal artery endothelium in situ by nitric oxide and reactive oxygen species. Kidney Int, 64: 199-207, 2003.

146. Nilius, B, Droogmans, G: Ion channels and their functional role in vascular endothelium. Physiol Rev, 81: 1415-1459, 2001.

147. Jiang, F, Li, CG, Rand, MJ: Mechanisms of nitric oxide-independent relaxations induced by carbachol and acetylcholine in rat isolated renal arteries. Br J Pharmacol, 130: 1191-1200, 2000.

148. Hille, B: Ion channels of excitable membranes. Sunderland, Mass: Sinauer, 2001.

149. Kohler, M, Hirschberg, B, Bond, CT, Kinzie, JM, Marrion, NV, Maylie, J, Adelman, JP: Small-conductance, calcium-activated potassium channels from mammalian brain. Science, 273: 1709-1714, 1996.

150. Ishii, TM, Silvia, C, Hirschberg, B, Bond, CT, Adelman, JP, Maylie, J: A human intermediate conductance calcium-activated potassium channel. Proc Natl Acad Sci U $S$ A, 94: 11651-11656, 1997.

151. Strobaek, D, Teuber, L, Jorgensen, TD, Ahring, PK, Kjaer, K, Hansen, RS, Olesen, SP, Christophersen, P, Skaaning-Jensen, B: Activation of human IK and SK Ca2+ activated K+ channels by NS309 (6,7-dichloro-1H-indole-2,3-dione 3-oxime). Biochim Biophys Acta, 1665: 1-5, 2004.

152. Dora, KA, Gallagher, NT, McNeish, A, Garland, CJ: Modulation of endothelial cell KCa3.1 channels during endothelium-derived hyperpolarizing factor signaling in mesenteric resistance arteries. Circ Res, 102: 1247-1255, 2008.

153. Sandow, SL, Neylon, CB, Chen, MX, Garland, CJ: Spatial separation of endothelial small- and intermediate-conductance calcium-activated potassium channels $(\mathrm{K}(\mathrm{Ca}))$ and connexins: possible relationship to vasodilator function? J Anat, 209: 689-698, 2006.

154. Sandow, SL, Haddock, RE, Hill, CE, Chadha, PS, Kerr, PM, Welsh, DG, Plane, F: What's where and why at a vascular myoendothelial microdomain signalling complex. Clin Exp Pharmacol Physiol, 36: 67-76, 2009.

155. Marrelli, SP, Eckmann, MS, Hunte, MS: Role of endothelial intermediate conductance KCa channels in cerebral EDHF-mediated dilations. Am J Physiol Heart Circ Physiol, 285: H1590-H1599, 2003.

156. Kwan, HY, Huang, Y, Yao, X: TRP channels in endothelial function and dysfunction. Biochim Biophys Acta, 1772: 907-914, 2007.

157. Bagher, P, Beleznai, T, Kansui, Y, Mitchell, R, Garland, CJ, Dora, KA: Low intravascular pressure activates endothelial cell TRPV4 channels, local $\mathrm{Ca} 2+$ events,

This article is protected by copyright. All rights reserved. 
and IKCa channels, reducing arteriolar tone. Proc Natl Acad Sci U S A, 109: 1817418179, 2012.

158. Ledoux, J, Taylor, MS, Bonev, AD, Hannah, RM, Solodushko, V, Shui, B, Tallini, Y, Kotlikoff, MI, Nelson, MT: Functional architecture of inositol 1,4,5-trisphosphate signaling in restricted spaces of myoendothelial projections. Proc Natl Acad Sci U S A, 105: 9627-9632, 2008.

159. Brasen, JC, Jacobsen, JC, Holstein-Rathlou, NH: The nanostructure of myoendothelial junctions contributes to signal rectification between endothelial and vascular smooth muscle cells. PLoS One, 7: e33632, 2012.

160. Edwards, G, Feletou, M, Weston, AH: Endothelium-derived hyperpolarising factors and associated pathways: a synopsis. Pflugers Arch, 459: 863-879, 2010.

161. Coleman, HA, Tare, M, Parkington, HC: Endothelial potassium channels, endotheliumdependent hyperpolarization and the regulation of vascular tone in health and disease. Clin Exp Pharmacol Physiol, 31: 641-649, 2004.

162. Emerson, GG, Segal, SS: Electrical coupling between endothelial cells and smooth muscle cells in hamster feed arteries: role in vasomotor control. Circ Res, 87: 474479, 2000.

163. Bussemaker, E, Popp, R, Binder, J, Busse, R, Fleming, I: Characterization of the endothelium-derived hyperpolarizing factor (EDHF) response in the human interlobar artery. Kidney Int, 63: 1749-1755, 2003.

164. de, WC, Wolfle, SE: EDHF and gap junctions: important regulators of vascular tone within the microcirculation. Curr Pharm Biotechnol, 8: 11-25, 2007.

165. Ellinsworth, DC, Earley, S, Murphy, TV, Sandow, SL: Endothelial control of vasodilation: integration of myoendothelial microdomain signalling and modulation by epoxyeicosatrienoic acids. Pflugers Arch, 466: 389-405, 2014.

166. Shimokawa, H: 2014 Williams Harvey Lecture: importance of coronary vasomotion abnormalities-from bench to bedside. Eur Heart J, 35: 3180-3193, 2014.

167. Ryan, MJ, Jernigan, NL, Drummond, HA, McLemore, GR, Jr., Rimoldi, JM, Poreddy, SR, Gadepalli, RS, Stec, DE: Renal vascular responses to CORM-A1 in the mouse. Pharmacol Res, 54: 24-29, 2006.

168. Boettcher, M, de, WC: Distinct endothelium-derived hyperpolarizing factors emerge in vitro and in vivo and are mediated in part via connexin 40-dependent myoendothelial coupling. Hypertension, 57: 802-808, 2011.

169. Wang, D, Borrego-Conde, LJ, Falck, JR, Sharma, KK, Wilcox, CS, Umans, JG: Contributions of nitric oxide, EDHF, and EETs to endothelium-dependent relaxation in renal afferent arterioles. Kidney Int, 63: 2187-2193, 2003.

170. Edgley, AJ, Tare, M, Evans, RG, Skordilis, C, Parkington, HC: In vivo regulation of endothelium-dependent vasodilation in the rat renal circulation and the effect of streptozotocin-induced diabetes. Am J Physiol Regul Integr Comp Physiol, 295: R829-R839, 2008.

171. von Beckerath, N, Dittrich, M, Klieber, HG, Daut, J: Inwardly rectifying K+ channels in freshly dissociated coronary endothelial cells from guinea-pig heart. J Physiol, 491 ( Pt 2): 357-365, 1996.

172. Forsyth, SE, Hoger, A, Hoger, JH: Molecular cloning and expression of a bovine endothelial inward rectifier potassium channel. FEBS Lett, 409: 277-282, 1997.

173. Sonkusare, SK, Dalsgaard, T, Bonev, AD, Nelson, MT: Inward rectifier potassium (Kir2.1) channels as end-stage boosters of endothelium-dependent vasodilators. $J$ Physiol, 594: 3271-3285, 2016.

This article is protected by copyright. All rights reserved. 
174. Ahn, SJ, Fancher, IS, Bian, JT, Zhang, CX, Schwab, S, Gaffin, R, Phillips, SA, Levitan, $\mathrm{I}$ : Inwardly-rectifying $\mathrm{K}+$ channels are major contributors to flow-induced vasodilation in resistance arteries. $J$ Physiol, 2016.

175. Minami, K, Fukuzawa, K, Nakaya, Y: Protein kinase C inhibits the $\mathrm{Ca}(2+)$-activated $\mathrm{K}+$ channel of cultured porcine coronary artery smooth muscle cells. Biochem Biophys Res Commun, 190: 263-269, 1993.

176. Salomonsson, M, Kornfeld, M, Gutierrez, AM, Magnusson, M, Persson, AE: Effects of stimulation and inhibition of protein kinase $\mathrm{C}$ on the cytosolic calcium concentration in rabbit afferent arterioles. Acta Physiol Scand, 161: 271-279, 1997.

177. Kirton, CA, Loutzenhiser, R: Alterations in basal protein kinase $C$ activity modulate renal afferent arteriolar myogenic reactivity. Am J Physiol, 275: H467-H475, 1998.

178. Sobey, CG: Potassium channel function in vascular disease. Arterioscler Thromb Vasc Biol, 21: 28-38, 2001.

179. Rusch, NJ, Liu, Y, Pleyte, KA: Mechanisms for regulation of arterial tone by Ca2+dependent K+ channels in hypertension. Clin Exp Pharmacol Physiol, 23: 1077-1081, 1996.

180. Giachini, FR, Carneiro, FS, Lima, VV, Carneiro, ZN, Dorrance, A, Webb, RC, Tostes, $\mathrm{RC}$ : Upregulation of intermediate calcium-activated potassium channels counterbalance the impaired endothelium-dependent vasodilation in stroke-prone spontaneously hypertensive rats. Transl Res, 154: 183-193, 2009.

181. Hilgers, RH, Webb, RC: Reduced expression of SKCa and IKCa channel proteins in rat small mesenteric arteries during angiotensin II-induced hypertension. Am J Physiol Heart Circ Physiol, 292: H2275-H2284, 2007.

182. LJ, J, Salomonsson, M, Sorensen, CM, Holstein-Rathlou, N, H, P, B, C, L, O, T, L: Potassium and calcium channel gene expression in small arteries in porcine and rat models of diet-induced obesity. Faseb Journal, 28, 2014.

183. Martens, JR, Gelband, CH: Alterations in rat interlobar artery membrane potential and K+ channels in genetic and nongenetic hypertension. Circ Res, 79: 295-301, 1996.

184. Mimuro, T, Kawata, T, Onuki, T, Hashimoto, S, Tsuchiya, K, Nihei, H, Koike, T: The attenuated effect of ATP-sensitive $\mathrm{K}+$ channel opener pinacidil on renal haemodynamics in spontaneously hypertensive rats. Eur J Pharmacol, 358: 153-160, 1998.

185. Michel, FS, Man, RY, Vanhoutte, PM: Increased spontaneous tone in renal arteries of spontaneously hypertensive rats. Am J Physiol Heart Circ Physiol, 293: H1673-1681, 2007.

186. Carmines, PK, Fujiwara, K: Altered electromechanical coupling in the renal microvasculature during the early stage of diabetes mellitus. Clin Exp Pharmacol Physiol, 29: 143-148, 2002.

187. Troncoso Brindeiro, CM, Lane, $\mathrm{PH}$, Carmines, $\mathrm{PK}$ : Tempol prevents altered $\mathrm{K}(+)$ channel regulation of afferent arteriolar tone in diabetic rat kidney. Hypertension, 59: 657-664, 2012.

188. Vallon, V, Albinus, M, Blach, D: Effect of KATP channel blocker U37883A on renal function in experimental diabetes mellitus in rats. J Pharmacol Exp Ther, 286: 12151221, 1998.

189. Zager, RA, Johnson, AC, Lund, S, Hanson, SY, Abrass, CK: Levosimendan protects against experimental endotoxemic acute renal failure. Am J Physiol Renal Physiol, 290: F1453-F1462, 2006.

190. da Rosa Maggi, SHB, Guarido, KL, de, SP, Crestani, S, da Silva-Santos, JE: Reduction in renal blood flow following administration of norepinephrine and phenylephrine in

This article is protected by copyright. All rights reserved. 
septic rats treated with Kir6.1 ATP-sensitive and KCa1.1 calcium-activated K+ channel blockers. Eur J Pharmacol, 765: 42-50, 2015.

191. Lange, M, Szabo, C, Van, AH, Williams, W, Traber, DL, Daudel, F, Broking, K, Salzman, AL, Bone, HG, Westphal, M: Short-term effects of glipizide (an adenosine triphosphate-sensitive potassium channel inhibitor) on cardiopulmonary hemodynamics and global oxygen transport in healthy and endotoxemic sheep. Shock, 26: 516-521, 2006.

192. Hall, S, Turcato, S, Clapp, L: Abnormal activation of K+ channels underlies relaxation to bacterial lipopolysaccharide in rat aorta. Biochem Biophys Res Commun, 224: 184190, 1996.

193. Morelli, A, Lange, M, Ertmer, C, Broeking, K, Van, AH, Orecchioni, A, Rocco, M, Bachetoni, A, Traber, DL, Landoni, G, Pietropaoli, P, Westphal, M: Glibenclamide dose response in patients with septic shock: effects on norepinephrine requirements, cardiopulmonary performance, and global oxygen transport. Shock, 28: 530-535, 2007.

194. Kane, GC, Lam, CF, O'Cochlain, F, Hodgson, DM, Reyes, S, Liu, XK, Miki, T, Seino, S, Katusic, ZS, Terzic, A: Gene knockout of the KCNJ8-encoded Kir6.1 K(ATP) channel imparts fatal susceptibility to endotoxemia. FASEB J, 20: 2271-2280, 2006.

195. O'Brien, AJ, Terala, D, Orie, NN, Davies, NA, Zolfaghari, P, Singer, M, Clapp, LH: BK large conductance $\mathrm{Ca}(2)+$-activated $\mathrm{K}+$ channel-deficient mice are not resistant to hypotension and display reduced survival benefit following polymicrobial sepsis. Shock, 35: 485-491, 2011.

196. Wei, AD, Gutman, GA, Aldrich, R, Chandy, KG, Grissmer, S, Wulff, H: International Union of Pharmacology. LII. Nomenclature and molecular relationships of calciumactivated potassium channels. Pharmacol Rev, 57: 463-472, 2005.

197. Kubo, Y, Adelman, JP, Clapham, DE, Jan, LY, Karschin, A, Kurachi, Y, Lazdunski, M, Nichols, CG, Seino, S, Vandenberg, CA: International Union of Pharmacology. LIV. Nomenclature and molecular relationships of inwardly rectifying potassium channels. Pharmacol Rev, 57: 509-526, 2005.

198. Gutman, GA, Chandy, KG, Grissmer, S, Lazdunski, M, McKinnon, D, Pardo, LA, Robertson, GA, Rudy, B, Sanguinetti, MC, Stuhmer, W, Wang, X: International Union of Pharmacology. LIII. Nomenclature and molecular relationships of voltagegated potassium channels. Pharmacol Rev, 57: 473-508, 2005.

199. Goldstein, SA, Bayliss, DA, Kim, D, Lesage, F, Plant, LD, Rajan, S: International Union of Pharmacology. LV. Nomenclature and molecular relationships of two-P potassium channels. Pharmacol Rev, 57: 527-540, 2005.

This article is protected by copyright. All rights reserved. 


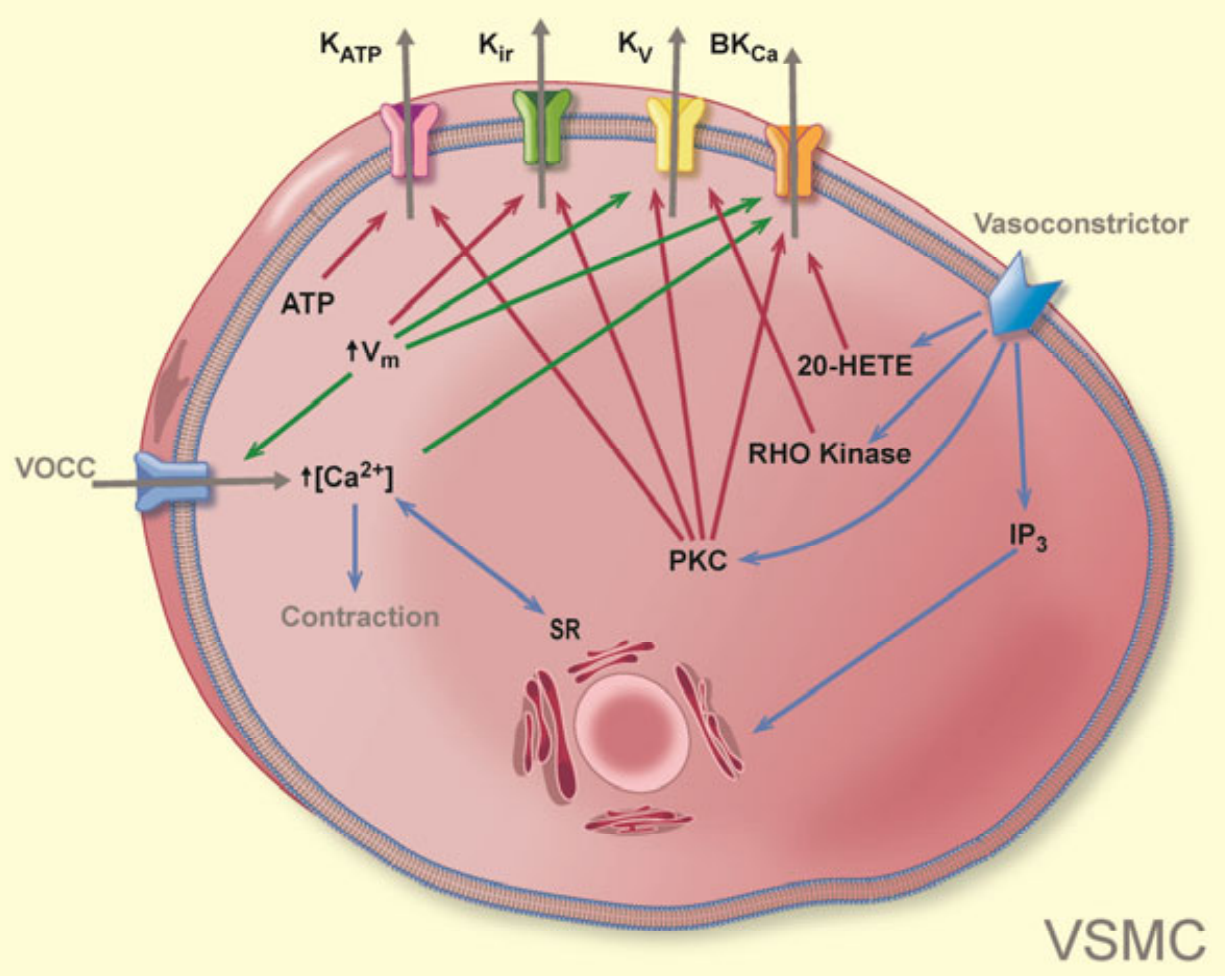

This article is protected by copyright. All rights reserved. 


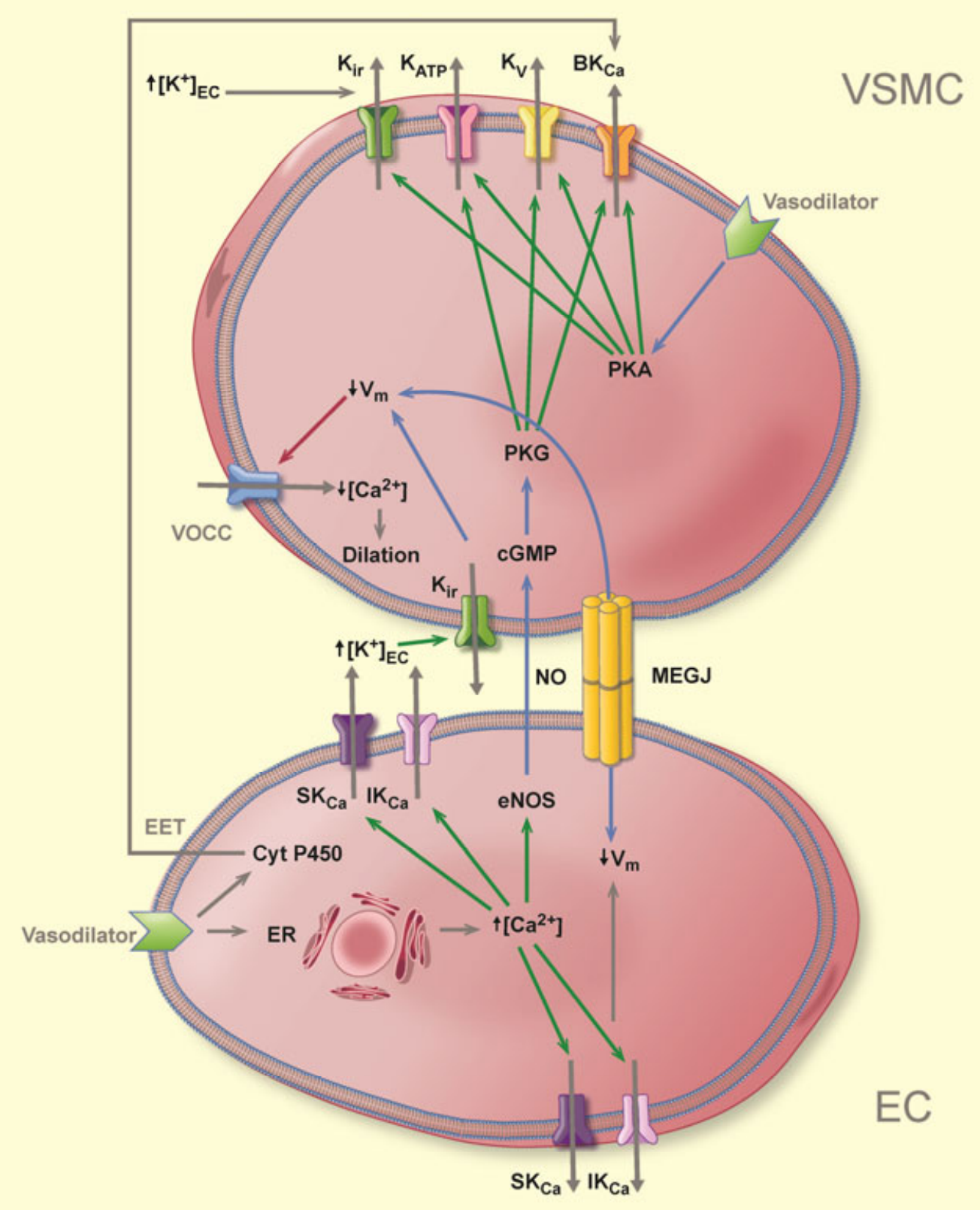

This article is protected by copyright. All rights reserved. 


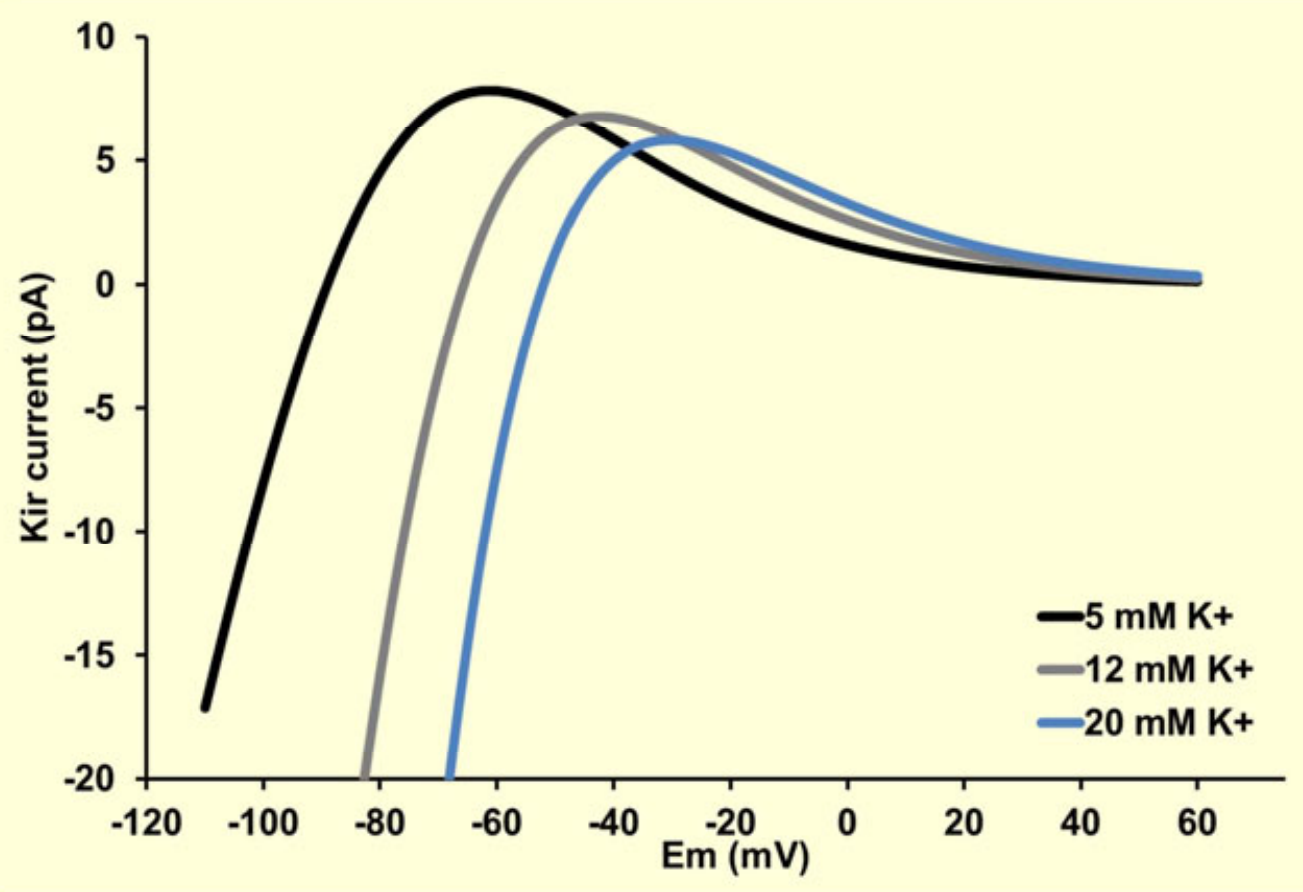

This article is protected by copyright. All rights reserved. 